\title{
GABAergic Inhibition of Histaminergic Neurons Regulates Active Waking But Not the Sleep-Wake Switch or Propofol-Induced Loss of Consciousness
}

\author{
Anna Y. Zecharia, ${ }^{1}$ Xiao Yu (喻晓), ${ }^{1}$ Thomas Götz, ${ }^{2}$ Zhiwen Ye (叶智文), ${ }^{1}$ David R. Carr, ${ }^{1}$ Peer Wulff, ${ }^{2}$ \\ Bernhard Bettler, ${ }^{3}$ Alexei L. Vyssotski, ${ }^{4}$ Stephen G. Brickley, ${ }^{1}$ Nicholas P. Franks, ${ }^{1}$ and William Wisden ${ }^{1}$ \\ ${ }^{1}$ Biophysics Section, Sir Ernst Chain Building, Department of Life Sciences, Imperial College London, London SW7 2AZ, United Kingdom, ${ }^{2}$ Institute of \\ Medical Sciences, University of Aberdeen, Foresterhill, Aberdeen AB25 2ZD, United Kingdom, ${ }^{3}$ Department of Biomedicine, Institute of Physiology, \\ University of Basel, CH-4056 Basel, Switzerland, and ${ }^{4}$ Institute of Neuroinformatics, University of Zurich/ETH Zurich, CH-8057 Zurich, Switzerland
}

The activity of histaminergic neurons in the tuberomammillary nucleus (TMN) of the hypothalamus correlates with an animal's behavioral state and maintains arousal. We examined how GABAergic inputs onto histaminergic neurons regulate this behavior. A prominent hypothesis, the "flip-flop" model, predicts that increased and sustained GABAergic drive onto these cells promotes sleep. Similarly, because of the histaminergic neurons' key hub-like place in the arousal circuitry, it has also been suggested that anesthetics such as propofol induce loss of consciousness by acting primarily at histaminergic neurons. We tested both these hypotheses in mice by genetically removing ionotropic $\mathrm{GABA}_{\mathrm{A}}$ or metabotropic $\mathrm{GABA}_{\mathrm{B}}$ receptors from histidine decarboxylase-expressing neurons. At the cellular level, histaminergic neurons deficient in synaptic $\mathrm{GABA}_{\mathrm{A}}$ receptors were significantly more excitable and were insensitive to the anesthetic propofol. At the behavioral level, EEG profiles were recorded in nontethered mice over $24 \mathrm{~h}$. Surprisingly, GABAergic transmission onto histaminergic neurons had no effect in regulating the natural sleep-wake cycle and, in the case of $\mathrm{GABA}_{\mathrm{A}}$ receptors, for propofolinduced loss of righting reflex. The latter finding makes it unlikely that the histaminergic TMN has a central role in anesthesia. $G_{A B A}$ receptors on histaminergic neurons were dispensable for all behaviors examined. Synaptic inhibition of histaminergic cells by $\mathrm{GABA}_{\mathrm{A}}$ receptors, however, was essential for habituation to a novel environment.

\section{Introduction}

The posterior hypothalamus contains circuitry governing the transition between wake and sleep (Haas and Panula, 2003; Saper et al., 2010). Within this area, the widely projecting and arousalpromoting histaminergic neurons, whose cell bodies are found exclusively in the tuberomammillary nucleus (TMN) (Watanabe et al., 1983; Panula et al., 1984), have a striking "wake-on, sleepoff" profile: histaminergic neurons do not fire action potentials during non-rapid eye movement (NREM) or REM sleep, but fire

\footnotetext{
Received June 20, 2012; accepted July 20, 2012.
}

Author contributions: A.Y.Z., T.G., S.G.B., N.P.F., and W.W. designed research; A.Y.Z., X.Y., T.G., Z.Y., D.R.C., and P.W. performed research; B.B. and A.L.V. contributed unpublished reagents/analytic tools; A.Y.Z., X.Y., T.G., Z.Y., D.R.C., P.W., S.G.B., N.P.F., and W.W. analyzed data; A.Y.Z., N.P.F., and W.W. wrote the paper.

This work was supported by the Medical Research Council (Grant G0800399 to P.W. and W.W.; and Grant G0901892 to N.P.F., S.G.B., and W.W.), the Biotechnology and Biological Sciences Research Council (Grant G021691 to N.P.F., S.G.B., and W.W.), the Wellcome Trust (S.G.B., N.P.F., and W.W.), UK-China Scholarships for Excellence/China Scholarship Council awards (to X.Y. and Z.Y.), and Imperial OA Publication Fund (W.W.). We are grateful to Lesley Cheyne (University of Aberdeen) and Raquel Yustos (Imperial College London) for technical support; to Dr. Lydia Teboul (MRC Harwell, Mary Lyon (entre, UK) for blastocyst injections; to Professor Werner Sieghart (University of Vienna, Austria) for kindly donating the $\gamma_{2}$ antibody; and to Dr. Valentina Ferretti and Eleonora Steinberg for comments on the manuscript.

This article is freely available online through the J Neurosci Author Open Choice option.

Correspondence should be addressed to either Nicholas P. Franks or William Wisden, Biophysics Section,

Sir Ernst Chain Building, Department of Life Sciences, Imperial College London, London SW7 2AZ, UK. E-mail: n.franks@imperial.ac.uk or w.wisden@imperial.ac.uk.

T. Götz's present address: Experimentelle Psychiatrie, Universitätsklinikum Carl Gustav Carus an der Technischen University of Dresden, 01307 Dresden, Germany.

DOI:10.1523/JNEUROSCI.2931-12.2012

Copyright $\odot 2012$ the authors $\quad 0270-6474 / 12 / 3213062-14 \$ 15.00 / 0$ tonically during wake (Haas and Panula, 2003; Takahashi et al., 2006, 2010; Sakai et al., 2010). Consequently, histaminergic neurons have been placed at the center of the "flip-flop" hypothesis of sleep regulation (Saper et al., 2010). In this model, continuous GABAergic and galaninergic inhibition from sleep-active neurons in preoptic hypothalamic nuclei onto histaminergic cells has been suggested to convey a sleep drive, which, through switching off histaminergic neurons as well as other arousal centers, allows sleep induction and maintenance (Sherin et al., 1996, 1998; Szymusiak et al., 1998; Saper et al., 2010).

Given the histaminergic system's wide influence on brain function and its putative role in sleep-wake control, it was compelling to suggest that some anesthetics might act selectively on $\mathrm{GABA}_{\mathrm{A}}$ receptors on these neurons to induce loss of consciousness (LOC) (Nelson et al., 2002; Zecharia et al., 2009). Allosteric modulators such as the anesthetic propofol increase GABA's apparent affinity at $\mathrm{GABA}_{\mathrm{A}}$ receptors, enhancing the chloride current (Rudolph and Mohler, 2004; Bonin and Orser, 2008; Franks, 2008; Olsen and Sieghart, 2009; Vithlani et al., 2011). Because histaminergic neurons express the $\mathrm{GABA}_{\mathrm{A}}$ receptor $\alpha_{1}, \alpha_{2}, \alpha_{5}, \beta_{1}$, $\beta_{3}$, and $\gamma_{2}$ subunit genes (Sergeeva et al., 2002, 2010; Zecharia et al., 2009; Yanovsky et al., 2012) we and Nelson et al. (2002) hypothesized these cells could be primary targets for propofol. When the $\mathrm{GABA}_{\mathrm{A}}$ receptor antagonist gabazine (SR95531) was microinjected directly into the TMN, it reduced the duration of loss of righting reflex (LORR) obtained from systemically admin- 
istered propofol (Nelson et al., 2002). Furthermore, the GABA receptor agonist muscimol produced a dose-dependent LORR when injected into the TMN (Nelson et al., 2002), and this evidence has been used to further support the flip-flop hypothesis of the wake-to-sleep transition (Saper et al., 2010).

These injection approaches are open to interpretation. In the mouse, the small size of the ventral (Fig. 1) and other TMN regions makes precision lesions and drug infusions (e.g., muscimol) to study histaminergic neurons challenging. Thus, in principle, targeting all histidine decarboxylase (HDC) neurons genetically would be best. For this project, we re-examined, using cell type-selective genetic targeting with $\mathrm{HDC}$-Cre mice, how GABAergic inhibition of histaminergic neurons influences the sleep-wake cycle and the response to a clinically important GABAergic anesthetic, propofol.

\section{Materials and Methods}

All procedures involving experimental mice were in accordance with the United Kingdom Animals (Scientific Procedures) Act 1986.

Generation of HDC-Cre mice

Exon 12 of the $h d c$ gene was targeted by homologous recombination in mouse embryonic stem cells (type RI), placing the Cre ORF with an enhanced internal ribosomal entry site (IRES2i) between the stop codon and the polyadenylation signal of the $h d c$ gene (Fig. $2 A$ ). The genomic DNA containing the mouse $h d c$ gene (ENSEMBL gene ENSMUSG00000027360, located on chromosome 2) (Joseph et al., 1990; Suzuki-Ishigaki et al., 2000) was obtained on a bacterial artificial chromosome (BAC) by screening the PubMed Clone finder library (BAC no. RP23-361E18).

An internal 10kb SpeI-BglII fragment including exons 10-12 of the $h d c$ gene was identified to serve as homologous arm for the targeting and was ligated into a modified pBluescript (Agilent Technologies) vector with a SpeI-BglII (underlined) adapter (sense: 5' -TCGAGACTAGTCCC AGATCTC-3'; and antisense: 5'-TCGAGAGATCTGGGACTAGTC-3') in the polylinker region. Into this vector a CMV promoter-EGFP CDNASV40-polyA cassette was introduced outside the homologous region to serve as a detector for nonhomologous recombination (negative selection). Fluorescent stem cell colonies were not expected to be homologous recombinants. The EGFP was excised as a BamHI/XbaI fragment from pEGFP-N1 (Clontech) and placed into an expression vector to incorporate the CMV enhancer/promoter and the SV40 polyA into the design. Then the whole CMV-EGFP-pA cassette was excised as a SalI/NotI fragment and placed into the vector carrying the genomic fragment of the HDC gene. An internal $4 \mathrm{~kb}$ XhoI-AgeI fragment, containing exon 12, was cloned into pLitmus28 (New England Biolabs) to perform sitedirected mutagenesis on it, introducing a unique SalI site $28 \mathrm{bp} 3^{\prime}$ of the hdc gene's stop codon using the primer pair, sense: $5^{\prime}$-CCTCAATCAG AATGCAAGAGTCGACGTGCCTGTGCTTCAGGGAG-3'; and antisense: $5^{\prime}$-CTCCCT GAAGCACAGCAGGCACGTCGACTCTTGCATT CTGATTGG-3', and then were recloned into the donor plasmid. The introduced SalI site is underlined. An improved IRES2i was placed upstream of a humanized Cre recombinase reading frame (Shimshek et al., 2002) in the pLitmus38 vector. An frt-neo-frt cassette (Cope et al., 2004) was ligated as a SpeI fragment into the NheI site of the pL38 Ires2iCre plasmid. A linker was inserted (sense: GGTACCGAATTCGGGTCGAC GGC; and antisense: TTAAGCCGTCGACCCGAATTCGGTACCGC), introducing a unique EcoRI site (in italics) into the construct upstream of the IRESCre that would be later used in the genomic screening of targeted ES cells. The IRES-Cre-frt-neo-frt cassette was excised using SalI and cloned into the unique SalI site of the pBluescript-HDC (exons1012)-SpeI-BglII-CMVeGFP-pA plasmid to complete the targeting vector. The construct was confirmed by sequencing across all joins (Fig. $2 \mathrm{~A}$ ).

The targeting construct was linearized with NotI outside the short homology arm at the $3^{\prime}$ end of the targeting vector, and $40 \mu \mathrm{g}$ were electroporated with $240 \mathrm{~V}$ and $500 \mu \mathrm{F}$ into $2 \times 10^{7}$ RI ES cells (Nagy et al., 1993). After $10 \mathrm{~d}$ under G418 (Geneticin, $200 \mathrm{mg} / \mathrm{ml}$ ) selection, non-GFP-fluorescent ES cell clones were picked and expanded for
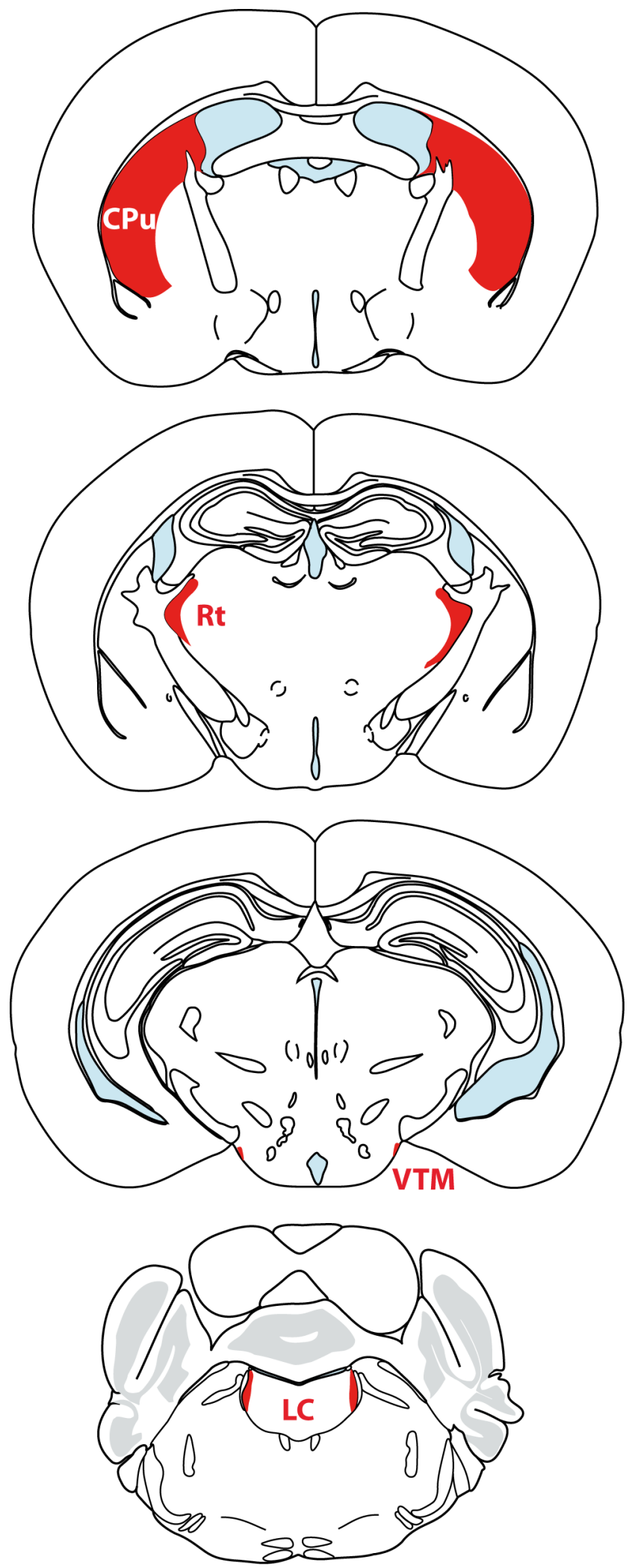

Figure 1. Coronal sections showing the relative sizes of selected mouse brain regions The caudate-putamen (Cpu), locus ceruleus (LC), reticular thalamic nucleus (Rt), and VTM are highlighted in red (adapted from Franklin and Paxinos, 2008).

analysis. Approximately 600 cell colonies were screened. The probe (Fig. $2 \mathrm{~A}$, Probe A) to perform Southern blotting was generated by PCR from the EcoRI genomic clone of the HDC gene. The primer pair for the 5' external probe was as follows: 5'A_S: 5' -CCATTCATCCGC 
GGTCATCTGGGAAACCATTG-3'; and 5'A_ AS: 5'-GCTATAGA ACTAAGTGAAAGGA AACTTGGTTG-3'.

Genomic DNA from the ES cells was digested with EcoRI, blotted, and hybridized with ${ }^{32}$ P-labeled $5^{\prime}$ external probe (Fig. $2 \mathrm{~A}$, Probe A). One clone was found targeted correctly. The targeted ES cell clone was injected by genOway into C57BL/6J blastocysts (Jackson Laboratories) to generate chimeric mice. Chimeras were selected for breeding with C57BL/6J mice to generate a stable mouse line, HDC-Cre. To remove the neo cassette from the genome, HDC-Cre mice were bred with Flp deleter mice (Rodríguez et al., 2000). Absence of the neo cassette was verified by Southern blot analysis with a neo probe.

\section{Generation of HDC-EGFP mice}

A second targeting vector was constructed so that, in addition to Cre recombinase, an EGFP reading frame was also driven from the HDC gene: i.e., a tricistronic $h d c$ gene was created (HDC-IRES-EGFP-IRES-Cre). The construction was similar to the one described for the HDC-Cre line. To transfer the IRES2i-EGFP as a BamHI fragment into pBluescript, a linker was inserted into the NotI site after the EGFP reading frame to introduce a second BamHI site (in italics) at the $3^{\prime}$ end (primer pair: $5^{\prime}$ -

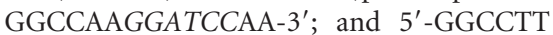
GGATCCTT-3'). An IRES2i-EGFP-IRES2iCre cassette was excised as the SalI-NheI fragment and transferred into pLitmus 38 via SalI/ NheI sites. Into this plasmid, a SpeI-frt-neofrt-SalI-SpeI fragment was inserted into the NheI site at the $3^{\prime}$ end. To apply the same screening strategy as for the HDC-Cre mice, a linker containing an EcoRI site (in italics) was inserted, using the following primer pair: $5^{\prime}$ GGTACCGAATTCGGGTCGACGGC- ${ }^{\prime}$ and 5' -TTAAGCCG TCGACCCGAATTCGGTAC CGC-3'. The IRES2i-EGFP-IRES2i-Cre-frtneo-frt cassette was excised using Sall and cloned into the unique SalI site of the pBluescript-HDC (exons10-12)-SpeI-BglII -CMVeGFP-pA plasmid, described in the HDC-Cre section above, to complete the targeting vector. The construct was confirmed by sequencing across all recombinant joins. The NotI site of the pBluescript polylinker served to linearize the targeting construct before electroporation in ES cells (Fig. 2B). The initial assay for correct targeting was the same as for the HDC-Cre line (see above). One clone, from a screen of $\sim 500$ stem cell colonies, was expanded and injected into blastocysts at MRC Harwell. Germline transmission was confirmed by Southern blotting (Fig. $2 B$ ) and PCR of ear genomic DNA with EGFP-specific primers. The neomycin cassette was removed by crossing with Flp deleter mice (Rodríguez et al., 2000).

\section{Mouse breeding}

For the experimental breedings, all the offspring were genotyped by PCR analysis using genomic DNA from ears or tails and the following specific primers: Cre: forward: $5^{\prime}$-GTGTGGCTGCCCCTTCTGCC-3'; reverse: $5^{\prime}$ AGCCTCACCATGGCCCCAGT-3' (250 bp) (Shimshek et al., 2002); $H D C-\Delta \gamma_{2}$ LoxP: forward: 5'-GTCATGCTAAATATCCTACAGTGG-3'; reverse: 5'-GGATAGTGCATCAGCAGACAATAG-3' (213 bp wild-type; 250 bp floxed allele) (Wulff et al., 2007); HDC- $\Delta B 1$ LoxP: forward: $5^{\prime}$-TG GGGTGTGTCCTACATGCAGCGGACGG-3'; reverse: 5'-GCTCTTCACC TTTCAACCCAGCCTCAGGCAGGC-3' (526 bp wild-type 742 bp floxed allele) (Haller et al., 2004); and EGFP: forward: 5' -CATTGTATGGGATC TGATCTG-3' ${ }^{\prime}$ reverse: $5^{\prime}$-TGAACTTGTGGCCGTTTA-3' (224 bp). To as- sess Cre recombinase expression, the HDC-Cre mice were crossed with the ROSA26-lacZ mice (Soriano, 1999). To generate the HDC- $\Delta \gamma_{2}$ and HDC$\triangle B 1$ animals, $H D C$-Cre mice were crossed with the $\gamma_{2}$ loxI77 (Wulff et al., 2007) or loxGABAB1 mice (Haller et al., 2004). Experiments used adult mice of either sex homozygous for the conditional $\gamma_{2}$ or $\mathrm{GABA}_{\mathrm{B} 1}$ allele, and heterozygous for the HDC-Cre transgene $\left(H D C-\Delta \gamma_{2}\right)$ and HDC-Crenegative littermate controls.

$\gamma_{2}$ loxI77 mice. The $\gamma_{2}$ subunit is essential for the $\mathrm{GABA}_{\mathrm{A}}$ receptor's placement at the postsynaptic membrane and for a full single-channel conductance (Pritchett et al., 1989; Seeburg et al., 1990; Günther et al., 1995; Lorez et al., 2000; Schweizer et al., 2003; Wulff et al., 2007, 2009a,b; Tretter et al., 2009). Genetically removing the $\gamma_{2}$ subunit eliminates fast synaptic inhibition (Schweizer et al., 2003, 2007, 2009a,b), and mice with a total knockout of the $\gamma_{2}$ subunit gene die postnatally (Günther et al., 1995). The $\gamma 2$ loxI77 line has been previously used by us to selectively remove synaptic $\mathrm{GABA}_{\mathrm{A}}$ receptor-mediated inhibition from Purkinje cells (Wulff et al., 2007,b) and other parvalbuminergic cells (Wulff et al., 2009a; Leppä et al., 2011). The F77I mutation does not affect the physiological properties of the $\mathrm{GABA}_{\mathrm{A}}$ receptor complex (Cope et al., 2004; Wulff et al., 2007), mice with the F77I mutation appear unimpaired on tests such as SHIRPA (Cope et al., 2004; Wulff et al., 2007; see below, SHIPRA analysis), and there is no effect on IPSC properties in a range of cell types (e.g., hippocampal pyramidal cells, hippocampal interneurons, 
cerebellar Purkinje cells, and cerebellar stellate and basket cells) (Cope et al., 2005; Wulff et al., 2007).

Lox GABAB1 mice. The $\mathrm{GABA}_{\mathrm{B}} \mathrm{R} 1$ subunit is an essential component of all $\mathrm{GABA}_{\mathrm{B}}$ receptors (Gassmann and Bettler, 2012); mice with a disrupted $G A B A B 1$ subunit gene have no $\mathrm{GABA}_{\mathrm{B}}$ receptor responses, have spontaneous epileptic seizures, and can die postnatally depending on the genetic background (Prosser et al., 2001; Schuler et al., 2001). Mice with the floxed GABAB1 allele used here have lox511 sites placed around exons 7 and 8 of the GABAB1 gene (Haller et al., 2004).

\section{In situ hybridization}

In situ hybridization was performed as previously described (Wisden and Morris, 1994). The oligodeoxyribonucleotide sequences used were as follows:HDC:5'-GCTGTCGGGTTCCTCGGGAGCACTCGCAGGTAGCTG GGCTCGCAG-3'; $\gamma 2$-Ex4: 5'-GTGTCTGGAATCCAGATTTTCCCCAC CATATTGCTATTCAAC-3'; and GABAB-R1: 5'-GAGGAGTTCATG GCCCGGTAGATTTGGTCTGTAATGGTCTGGTTG-3' .

Nonperfused brains were removed and frozen on dry ice. Sections (14 $\mu \mathrm{m})$ were cut on a cryostat, mounted onto poly-L-lysine-coated slides, and dried at room temperature. Sections were fixed in $4 \%$ paraformaldehyde, washed in PBS, and dehydrated into $95 \%$ ethanol for storage at $4^{\circ} \mathrm{C}$. Before hybridization, sections were removed from ethanol and allowed to air dry. Probes $(0.3 \mathrm{pmol} / \mu \mathrm{l})$ were $3^{\prime}$ end labeled using terminal deoxynucleotidyl transferase (Roche Diagnostics) and a 30:1 molar ratio of $\alpha^{33} \mathrm{PdATP}(250 \mu \mathrm{Ci} / \mu \mathrm{l}$; PerkinElmer) to oligonucleotide. Labeled probe, dissolved in hybridization buffer, was applied to sections. Hybridization buffer contained $50 \%$ formamide/ $4 \times$ SSC/10\% dextran sulfate $\left(1 \times\right.$ SSC: $0.15 \mathrm{M} \mathrm{NaCl}, 0.015 \mathrm{M} \mathrm{Na}$-citrate). Hybridization was at $42^{\circ} \mathrm{C}$ overnight. Sections were washed with $1 \times$ SSC at room temperature for 5 $\mathrm{min}, 1 \times \mathrm{SSC}$ at $65^{\circ} \mathrm{C}$ for $40 \mathrm{~min}, 0.1 \times \mathrm{SSC}$ for $1 \mathrm{~min}$ at room temperature, and $70 \%$ ethanol for $1 \mathrm{~min}$ at room temperature before $95 \%$ ethanol dehydration. Images were generated from 1 to 2 week exposures to Biomax MR x-ray film (Eastman Kodak). To assess nonspecific labeling of the sections, each labeled oligodeoxyribonucleotide was hybridized to brain sections with a 100-fold excess of unlabeled oligodeoxyribonucleotide.

Immunohistochemistry and $\beta$-galactosidase labeling

Adult mice were transcardially perfused with ice-cold $4 \%$ paraformaldehyde (PFA; obtained as a $16 \%$ solution from Thermo Scientific) in PBS (Sigma-Aldrich) at pH 7.4. Brains were removed and post-fixed overnight before cryoprotection with 30\% sucrose in PBS. Brains were frozen on dry ice, and $40 \mu \mathrm{m}$ coronal sections were cut using a vibratome. Free-floating sections were washed in PBS three times for $10 \mathrm{~min}$, permeabilized in PBS plus $0.4 \%$ Triton X-100 for 30 min, blocked by incubation in PBS plus $4-10 \%$ normal goat serum (NGS), $0.2 \%$ Triton X-100 for $1 \mathrm{~h}$ (all at room temperature), and subsequently incubated with a primary antibody diluted in PBS plus $2 \%$ NGS overnight at $4^{\circ} \mathrm{C}$. Incubated slices were washed three times in PBS plus 1\% NGS for $10 \mathrm{~min}$ at room temperature, incubated for $2 \mathrm{~h}$ at room temperature with secondary antibody in PBS plus $1 \%$ NGS, and subsequently washed three times in PBS plus $1 \%$ NGS or PBS alone for $10 \mathrm{~min}$ at room temperature. Primary antibodies used were rabbit polyclonal EGFP (Invitrogen, 1:1000), guinea pig polyclonal HDC (American Research Products, 1:200), rabbit polyclonal HDC (Immuno Diagnostics, 1:1000), mouse monoclonal $\beta$-Gal (Promega, 1:5000), rabbit polyclonal $\gamma_{2}$ (kindly donated by Professor Werner Sieghart, University of Vienna, Vienna, Austria, 1:200), and rabbit polyclonal anti-GABA $\mathrm{B}_{\mathrm{B} 1}$ antibody Ab25, diluted 1:1000 (Engle et al., 2006). Secondary antibodies were Alexa Fluor 488 goat anti-rabbit IgG (1:1000), Alexa Fluor 594 goat anti-guinea pig IgG (1:1000), Alexa Fluor 488 goat anti-mouse IgG (Invitrogen, 1:1000), CY3 goat anti-rabbit IgG (Stratech Scientific, 1:1000). For immunostaining after experimental recordings, neurons were filled by adding biocytin to the pipette solution. Slices were fixed with a freshly prepared solution of 4\% 1-Ethyl-3(3dimethylamino-propyl)carbodiimide and $1 \% \mathrm{~N}$-hydroxysuccinimide in $0.1 \mathrm{~m}$ phosphate buffer $(\mathrm{PB}), \mathrm{pH} 7.4\left(2-12 \mathrm{~h}\right.$ at $\left.4^{\circ} \mathrm{C}\right)$ and then stained with a rabbit anti-histamine (Millipore Bioscience Research Reagents, 1:1000) polyclonal antibody (Panula et al., 1984). Slices were then incubated at room temperature with sheep anti-rabbit Cy3 (1:500) and streptavidin-Alexa 488 (Invitrogen, 1:200). Slices were analyzed using an upright fluorescent Nikon eclipase $80 i$ or a Zeiss LSM 510 confocal microscope. $\beta$-galactosidase (lacZ) staining was performed as previously described (Bahn et al., 1997). Brain sections were prepared as described above and incubated free floating in 5-bromo-4-chloro-3-indolyl- $\beta$-galactoside (X-Gal) at $37^{\circ} \mathrm{C}$ (Bonnerot and Nicolas, 1993). After X-Gal staining, sections were post-fixed in ice-cold 4\% PFA for $15 \mathrm{~min}$, rinsed in $100 \mathrm{~mm}$ $\mathrm{PB}, \mathrm{pH} 7.4$, and mounted.

\section{Brain slice electrophysiology}

We recorded whole-cell action potential firing and examined GABAergic currents in histaminergic neurons of the posterior hypothalamus [Fig. 1, ventral tuberomammillary (VTM) nucleus] and dorsal lateral geniculate (DLG) nucleus in acute coronal slices (Bright et al., 2007; Zecharia et al., 2009).

Adult mice were deeply anesthetized with halothane and killed by decapitation. The brain was rapidly removed and immersed in ice-cold slicing solution [slicing ACSF contained the following (in $\mathrm{mm}$ ): $2.5 \mathrm{KCl}$, $1 \mathrm{CaCl}_{2}, 5 \mathrm{MgCl}, 1.25 \mathrm{NaH}_{2} \mathrm{PO}_{4}, 26 \mathrm{NaHCO}_{3}$ and 11 glucose] bubbled with $95 \% \mathrm{O}_{2} / 5 \% \mathrm{CO}_{2}$. The tissue block was cut between the cerebellum and optic tract, and brain slices were produced with a vibratome tissue slicer (Campden Instruments). Coronal slices were cut at a thickness of $250 \mu \mathrm{m}$ and transferred to a holding chamber containing cold slicing ACSF continuously bubbled with $95 \% \mathrm{O}_{2} / 5 \% \mathrm{CO}_{2}$. Once slicing was complete, the holding chamber was transferred to a $37^{\circ} \mathrm{C}$ heat block for 15 min, after which the slicing ACSF was gradually exchanged for recording ACSF [which contained the following (in $\mathrm{mm}$ ): $125 \mathrm{NaCl}, 2.5 \mathrm{KCl}, 2$ $\mathrm{CaCl}_{2}, 2 \mathrm{MgCl}, 1.25 \mathrm{NaH}_{2} \mathrm{PO}_{4}, 26 \mathrm{NaHCO}_{3}$, and 11 glucose, $\mathrm{pH} 7.4$ when bubbled with $95 \% \mathrm{O}_{2} / 5 \% \mathrm{CO}_{2}$ ] over $40 \mathrm{~min}$, then allowed to reach room temperature before electrophysiological recording experiments.

Neurons were visualized by using a fixed-stage upright microscope (Slice Scope Pro 1000, Scientifica) fitted with a high numerical aperture water-immersion objective (Olympus, $40 \times / 0.8 \mathrm{~W}$ LUMPlanFL N), and a digital camera. The recording chamber was continuously perfused with external solution (containing $1.5 \mu \mathrm{M}$ propofol from a $15 \mathrm{~mm}$ ethanolic stock when appropriate) via a gravity perfusion system at a rate of 3 $\mathrm{ml} / \mathrm{min}$. Patch pipettes were fabricated from thick-walled borosilicate glass capillaries ( $1.5 \mathrm{~mm}$ outer diameter, $0.86 \mathrm{~mm}$ inner diameter; Harvard Apparatus) using a two-step vertical puller (Narishige PC-10). Pipette resistances were typically $<5 \mathrm{M} \Omega$ when back-filled with internal solution.

We identified histaminergic neurons by the presence of hyperpolarization-activated current $\left(I_{\mathrm{h}}\right)$ and a transient outward current (Stevens et al., 2001), their spontaneous firing activity, and/or doubleimmunostaining for histamine and biocytin (included in the pipette solution at $1.5 \mathrm{mg} / \mathrm{ml}$, Sigma). We visually identified the DLG nucleus under low power and selected large $(>50 \mathrm{pF})$ relay neurons within this area. For examination of IPSCs, we performed whole-cell patch recordings in voltage-clamp $(-60 \mathrm{mV})$ using internal pipette solutions containing the following (in mM): $140 \mathrm{CsCl}, 4 \mathrm{NaCl}, 0.5 \mathrm{CaCl}_{2}, 10 \mathrm{HEPES}, 5$ EGTA, and $2 \mathrm{Mg}$-ATP; the $\mathrm{pH}$ was adjusted to 7.3 with $\mathrm{CsOH}$. For examination of neuronal firing properties, we recorded in current-clamp using internal solutions containing the following (in $\mathrm{mM}$ ): 145 K-gluconate, $4 \mathrm{NaCl}, 5 \mathrm{KCl}, 0.5 \mathrm{CaCl}_{2}$, 5 EGTA, $10 \mathrm{HEPES}, 4 \mathrm{Mg}$-ATP, and 5 sucrose; the $\mathrm{pH}$ was adjusted to 7.3 with $\mathrm{KOH}$.

The amplifier headstage was connected to an Axopatch 200B or 700B amplifier (Molecular Devices). Fine and course movements of the pipettes were controlled by micromanipulators (PatchStar, Scientifica) mounted on a fixed platform. The amplifier current output was filtered at $10 \mathrm{kHz}(-3 \mathrm{~dB}$, eight-pole low-pass Bessel filter) and digitized at $50 \mathrm{kHz}$ using a Cambridge Electronic Devices (CED $1401 \mathrm{mk}$ II) or National Instruments digitization board (NI-DAQmx, PCI-6052E). Data acquisition was performed by using WINWCP (version 4.1.2) and WINEDR (version 3.0.9), kindly provided by John Dempster (University of Strathclyde, Glasgow, UK).

\section{SHIPRA analysis}

A basic behavioral characterization of the mice was performed. Naive adult animals were screened in a modified SHIRPA (http://empress.har. mrc.ac.uk/browser/?sop_id = 10_002_0) by an observer blind to the genotype (Leppä et al., 2011). Twenty-three primary physiological and 
Table 1. Results of the SHIRPA screen on HDC- $\Delta \gamma_{2}$ and $H D C-\Delta B 1$ mice compared with littermate controls

\begin{tabular}{lllll}
\hline Parameter measured & $\begin{array}{l}H D C-\Delta \gamma 2 \\
(n=13)\end{array}$ & $\begin{array}{l}\text { Littermate } \\
(n=11)\end{array}$ & $\begin{array}{l}H D C-\Delta B 1 \\
(n=10)\end{array}$ & $\begin{array}{l}\text { Littermate } \\
(n=10)\end{array}$ \\
\hline Body position & 0 & 0 & 0 & 0 \\
Appearance & 0 & 0 & 0 & 0 \\
Whiskers & 0 & 0 & 0 & 0 \\
Tremor & 0 & 0 & 0 & 0 \\
Palpebral closure & 0 & 0 & 0 & 0 \\
Lacrimation & 0 & 0 & 0 & 0 \\
Defecation & 0 & 0 & 0 & 0 \\
Grooming & 0 & 0 & 0 & 0 \\
Transfer arousal & 0 & 0 & 0 & 0 \\
Locomotor activity & 0 & 0 & 0 & 0 \\
Gait & 0 & 0 & 0 & 0 \\
Stretch & 0 & 0 & 0 & 0 \\
Tail elevation & 0 & 0 & 0 & 0 \\
Startle response & $\mathrm{nm}$ & $\mathrm{nm}$ & 0 & 0 \\
Touch escape & 0 & 0 & 0 & 0 \\
Positional passivity & 0 & 0 & 0 & 0 \\
Trunk curl & 0 & 0 & 0 & 0 \\
Limb grasping & 0 & 0 & 0 & 0 \\
Pinna reflex & 0 & 0 & 0 & 0 \\
Corneal reflex & 0 & 0 & 0 & 0 \\
Contact righting reflex & 0 & 0 & 0 & 0 \\
Evidence of biting & 0 & $0.9 \pm 1.2$ & $31.7 \pm 2.0$ \\
Vocalization & 0 & 0 & 0 & 0 \\
Weight (g) & $34.31 \pm 1.5)$ & 0 & 0 & 0 \\
\hline nm & 0 & 0 & 0 & 0 \\
\hline
\end{tabular}

$\mathrm{nm}$, Not measured. There was also no difference in the weight of knockouts compared to littermates.

behavioral parameters were recorded and videotaped in a glass viewing chamber (height, $18 \mathrm{~cm}$; diameter, $14 \mathrm{~cm})$ and open field arena $(27 \times 27$ $\mathrm{cm})$. Table 1 shows the SHIRPA data for the HDC- $\Delta \gamma_{2}$ and $H D C-\Delta B 1$ mice. Wilcoxon signed rank tests or Mann-Whitney tests, used as appropriate, revealed no significant differences between the respective knockouts and littermate controls.

\section{EEG recording and behavior}

Mice were implanted with EEG and EMG electrodes under general anesthesia (Pang et al., 2009). After a minimum $7 \mathrm{~d}$ recovery period, we recorded cortical activity and muscle tone using Neurologger 2 devices, as described previously (Pang et al., 2009; Vyssotski et al., 2009). These data loggers connect directly to electrode pins, which enabled us to make untethered recordings (i.e., freely moving mice) in the home cage or other environment. For all recordings, mice were acclimatized to the Neurologger 2 by attaching a mock logger (similar size and weight) for 2-3 d before the experiment. For natural sleep recordings, which all took place in the animals' home cages, animals were connected to the Neurologger $2 \sim 2 \mathrm{~h}$ before "lights on" and moved to a sound-proof chamber. There were always at least 2 mice in the chamber per recording. Mice were left undisturbed for at least $24 \mathrm{~h}$ to enable a full sleep-wake cycle ( 12 $\mathrm{h}$ light, $12 \mathrm{~h}$ dark) to be recorded. For litter change experiments, mice were connected to the Neurologger 2 and transferred to the sound-proof chamber in their home cage $3 \mathrm{~h}$ before lights on, and transferred to a new home cage containing fresh bedding $1 \mathrm{~h}$ before lights on. Mice were left undisturbed overnight to assess their response to the new environment. The sleep state (REM; NREM; or WAKE) was scored automatically using an established protocol (Costa-Miserachs et al., 2003; Pang et al., 2009).

For propofol-induced LORR, mice were placed in a restraining tube and injected (intravenously in the tail) with 10 or $30 \mathrm{mg} / \mathrm{kg}$ propofol (Rapinovet; Schering-Plough Animal Health). Mice were removed from the tube and placed on a heated mat. Animals were turned onto their side every $30 \mathrm{~s}$, and the time to spontaneous righting was recorded. For propofol-induced motor sedation, mice were injected (50 mg/kg, i.p.) and immediately placed in an Activity Monitor (Med Associates). The coordinates of the animal were recorded using two orthogonal sets of 16 infrared beams for $10 \mathrm{~min}$. Data were analyzed with Activity Monitor software (Med Associates). The Activity Monitor was thoroughly cleaned with ethanol between experiments. To reduce our cohort size, we compared propofol motor sedation with vehicle (20\% Intralipid, Fresenius Kabi) in a single animal by paired experiments. Experiments were at least $7 \mathrm{~d}$ apart, and the injection order (vehicle versus propofol) was randomized across the cohort.

Data are presented as the mean \pm SEM, and an unpaired Student's $t$ test was used for statistical analysis (unless otherwise stated), using Welch's correction for unequal variance, when appropriate. All statistical analysis was performed using GraphPad Prism version 4.03 for Windows.

\section{Results}

\section{Genetic targeting of histaminergic neurons}

We first generated a mouse line that would allow us to specifically manipulate histaminergic (HDC-expressing) neurons. For the $h d c$ gene, we chose to knock in Cre to the endogenous $h d c$ allele on chromosome 2 at the end of the $h d c$ reading frame rather than use a BAC transgene; the small $(12 \mathrm{~Kb}) h d c$ gene is located in a gene-dense area, and, depending on the size of any BAC used for a transgene, extra genes might be introduced on the BAC. By homologous recombination in embryonic stem cells, an IRESCre recombinase cassette was placed after the stop codon in exon 12 of the mouse $h d c$ gene on chromosome 2 to create the $h d c$-Cre knock-in allele (Fig. $2 A$ ). The mRNA produced from this $h d c$-Cre allele encodes both HDC protein and Cre recombinase (Fig. $2 \mathrm{~A}$ ). In situ hybridization with an HDC-specific oligonucleotide probe confirmed that in adult wild-type mice HDC mRNA was restricted to the TMN (Fig. 3A) (Bayliss et al., 1990; Karlstedt et al., 2001). We mapped $h d c$-Cre gene expression by crossing HDCCre mice with ROSA26-lacZ reporter mice (Fig. 3C,E,F) (Soriano, 1999). Adult brains of these offspring had the expected $\beta$-galactosidase expression in the TMN and ependyma (Fig. $3 C$ ); $\beta$-galactosidase staining, which appeared as puncta within the cells, was colocalized with HDC immunoreactivity (Fig. 3D). $\beta$-galactosidase staining was absent from most other adult brain regions of HDC-Cre $\times$ ROSA26-lacZ brains (e.g., olfactory bulb, neocortex, hippocampus, striatum, most of the thalamus and hypothalamus, the raphe nuclei, and locus ceruleus). However, lacZ was expressed, unexpectedly, in a few thalamic nuclei: the dorsal lateral geniculate nucleus (Fig. $3 E, F$ ); the ventral posterolateral thalamus (VPL) nuclei (Fig. $3 F)$; and scattered cells in the post-thalamic nucleus. There was also lacZ expression in the ventral medial hypothalamus (VMH) (Fig. 3F), some cells in the inferior colliculi, and some cerebellar Purkinje cells. ROSA26-lacZ gene expression in these areas probably originated from transient $h d c$-Cre gene expression during development (see Discussion).

We also produced a tricistronic knock-in mouse line with an extra IRES element at the $h d c$ locus, so that the mRNA would contain three reading frames (HDC-IRES-EGFP-IRES-Cre) (Fig. $2 B$ ), and EGFP would be uniquely expressed in histaminergic neurons; in this additional line, however, Cre was not translated sufficiently from the second IRES element to enable recombination. So we termed this tricistronic line simply "HDC-EGFP." Unlike the case for the HDC-Cre $\times$ ROSA26-lacZ crosses, which reflect the developmental history of the $h d c$ gene expression, EGFP will only be present in cells when the $h d c$-EGFP gene is currently expressed. Thus, the HDC-EGFP line was convenient for mapping HDC cells in adult mice by immunohistochemistry with an EGFP-specific antibody (Fig. 4). HDC-EGFP neurons were scattered throughout the TMN, dispersed as bilateral clusters in the VTM, medial tuberomammillary (MTM), and diffuse tuberomammillary (DTM) area; there were also positive cells in the dorsal part of the ependymal wall of the third 

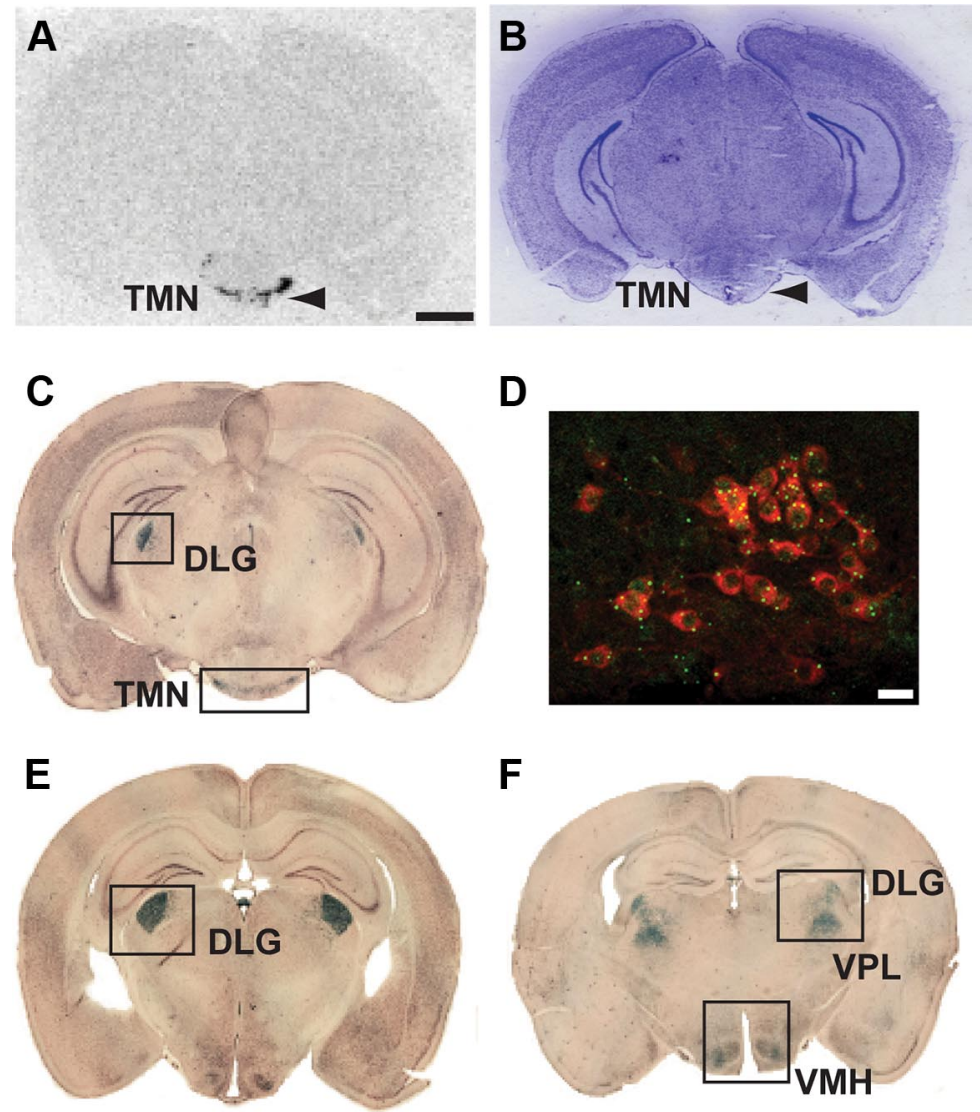

Figure 3. hdc gene expression and examination of (re recombinase activity using the ROSA26 reporter mouse. The $h d c$ cene was only expressed in the TMN in adult wild-type mice. $\boldsymbol{A}, \boldsymbol{B}$, hdc in situ hybridization with a ${ }^{33}$ P-labeled probe specific for $\operatorname{HDC}(\boldsymbol{A})$ and the corresponding Nissl-stained section $(\boldsymbol{B})$. Arrowheads indicate the TMN region in both panels. $\boldsymbol{C}$, Coronal brain section showing $\beta$-galactosidase staining (Cre recombination-positive, blue) in the TMN from ROSA26 $\times H D C$-Cre crosses. $\boldsymbol{D}$, Doubleimmunofluorescent labeling for $\beta$-galactosidase (green) and HDC (red) protein in coronal TMN sections from ROSA26 lacZ $\times$ $H D C$-Cre mice indicates efficient recombination in histaminergic neurons. $E, F, \beta$-galactosidase staining was also seen in the DLG VPL, and VMH. Scale bars: $A-C, E, F, 2 \mathrm{~mm} ; \boldsymbol{D}, 25 \mu \mathrm{m}$.

ventricle (Fig. 4A), in agreement with Karlstedt et al. (2001). By double staining, nearly all EGFP cells were HDC positive (Fig. $4 B-E$ ). In contrast to results with the brains from ROSA $\times$ HDC-Cre mice (Fig. $3 C, E, F$ ), but agreeing with in situ hybridization using HDC probes on wild-type mouse brain sections (Fig. $3 A$ ), no other brain areas in HDC-EGFP mice had EGFP immunoreactivity. So, in the adult mouse brain, $h d c$ gene expression is restricted to the TMN (see Discussion).

\section{Specific removal of synaptic $\mathrm{GABA}_{\mathrm{A}}$ receptors from histaminergic neurons}

Histaminergic neurons from the TMN express a mixture of $\mathrm{GABA}_{\mathrm{A}}$ receptor subunit genes $\left(\alpha_{1}, \alpha_{2}, \alpha_{5}, \beta_{1}, \beta_{3}\right.$, and $\left.\gamma_{2}\right)($ Sergeeva et al., 2002; Zecharia et al., 2009; Yanovsky et al., 2012), which means the receptors are $\alpha \beta \gamma_{2}$ types. We examined how fast GABAergic inhibition onto histaminergic neurons regulates the sleep-wake cycle by crossing HDC-Cre mice with a line containing a conditional gabrg2 allele $\left(\gamma_{2}\right.$ I77lox) (Wulff et al., 2007), where exon 4 is flanked by loxP sites, to produce HDC- $\Delta \gamma_{2}$ mice. Removal of the $\gamma_{2}$ subunit abolishes synaptic responses through $\mathrm{GABA}_{\mathrm{A}}$ receptors (Schweizer et al., 2003; Wulff et al., 2007, $2009 \mathrm{a}, \mathrm{b})$, since the $\gamma_{2}$ subunit anchors $\mathrm{GABA}_{\mathrm{A}}$ receptors at synapses and allows a sufficient single-channel conductance of 25-30 pS (Seeburg et al., 1990; Lorez et al., 2000; Schweizer et al.,
2003). Removal of $\gamma_{2}$ subunits leaves lowconductance $\alpha \beta$-type $\mathrm{GABA}_{\mathrm{A}}$ receptors that are extrasynaptic. A SHIRPA screen showed that the HDC- $\Delta \gamma_{2}$ mice were indistinguishable from their littermate controls in health, behavior, and appearance (Table 1). In situ hybridization with an exon 4-specific $\gamma_{2}$ subunit probe showed no gross change in $\gamma_{2}$ expression in any non-TMN brain region of HDC$\Delta \gamma_{2}$ mice compared with littermate control mice (see Fig. 5A); the $\mathrm{GABA}_{\mathrm{A}}$ receptor $\gamma_{2}$ gene is widely expressed in the adult mouse brain (Cope et al., 2004; Wulff et al., 2007, 2009a,b). Expression of $\gamma_{2}$ mRNA was unchanged in the thalamus, where its expression was weak in littermate controls (see Fig. 5Aii, DLG), hypothalamus (see Fig. $5 A i, \mathrm{VMH}$ ), and other brain areas such as the cerebellum and brainstem (see Fig. 5Aiii). In the TMN region, the $\gamma_{2}$ signal was diffuse in both littermate control and knock-out groups (see Fig. 5Aii); as histaminergic cells are scattered in this region (Fig. $4 A$ ), it was difficult to see a change in $\gamma_{2}$ mRNA signal. However, immunocytochemistry with a $\gamma_{2}$ subunit-specific antibody showed loss of signal in HDC-positive neurons (Fig. 5B), but not other brain regions. To further confirm loss of synaptic $\mathrm{GABA}_{\mathrm{A}}$ receptors, we recorded currents in whole-cell voltage-clamped neurons in acute adult slices containing the ventral TMN (Zecharia et al., 2009). Fast GABA receptor-mediated IPSCs were absent from ventral TMN neurons in the HDC$\Delta \gamma_{2}$ mice, but were present in those from littermate controls (Fig. 5C).

The results obtained with the HDC-Cre $\times$ Rosa 26 crosses implied that synaptic inhibition in $H D C-\Delta \gamma_{2}$ mice might be affected in some additional brain regions, such as a subset of thalamic relay nuclei (Fig. 3). We investigated whether this had happened for neurons in acutely prepared slices of the DLG nucleus. $\mathrm{GABA}_{\mathrm{A}}$ receptor-mediated inhibition in these thalamic relay neurons is a mixture of synaptic IPSCs and extrasynaptic tonic currents, with the majority of charge carried by the $\alpha_{4} \beta \delta$-type $\mathrm{GABA}_{\mathrm{A}}$ receptors (Belelli et al., 2005, 2009; Jia et al., 2005, 2009; Bright et al., 2007; Brickley and Mody, 2012). We found that the occurrence of IPSCs in DLG neurons had changed between HDC- $\Delta \gamma_{2}$ and littermate control mice. Even in control neurons, GABAergic IPSCs were not always observed (Fig. 5Di, see example). However, 12 of 16 $(\sim 85 \%)$ neurons in littermates (Fig. 4 Dii), but only 4 of 13 $(\sim 30 \%)$ DLG neurons in HDC- $\Delta \gamma_{2}$ mice had IPSCs (Fig. $5 E$ ). This difference was significant $\left(\chi^{2}\right.$ test, $\chi^{2}=7.35 ; \mathrm{df}=1 ; p=$ 0.01 ). As approximately a third of the $H D C-\Delta \gamma_{2}$ DLG neurons still have IPSCs, this partial ablation has most likely come about because Cre expression was transient during development, and, in contrast to the Rosa locus, the $\gamma_{2}$ lox allele may not be as susceptible to recombination unless sustained Cre levels are present (see Discussion). 

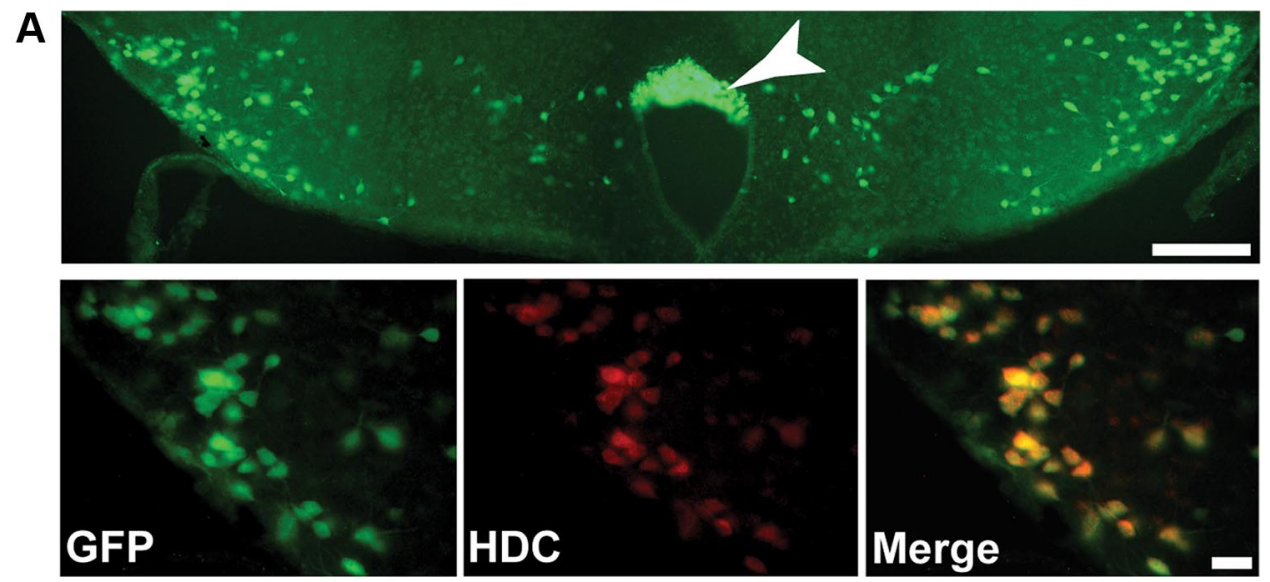

B
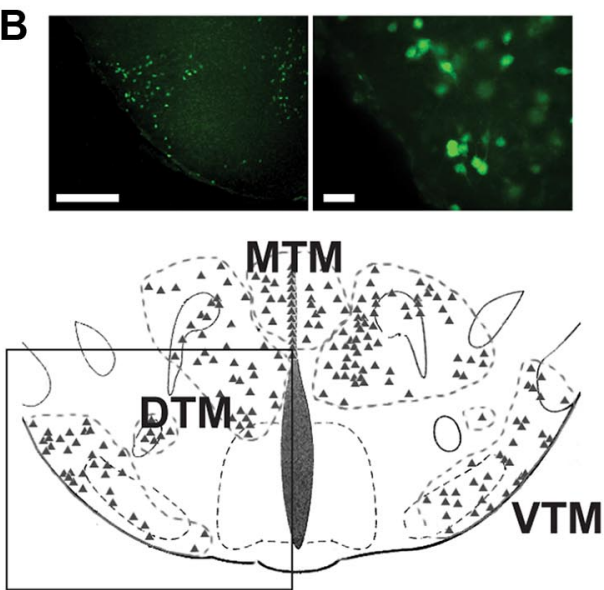

D
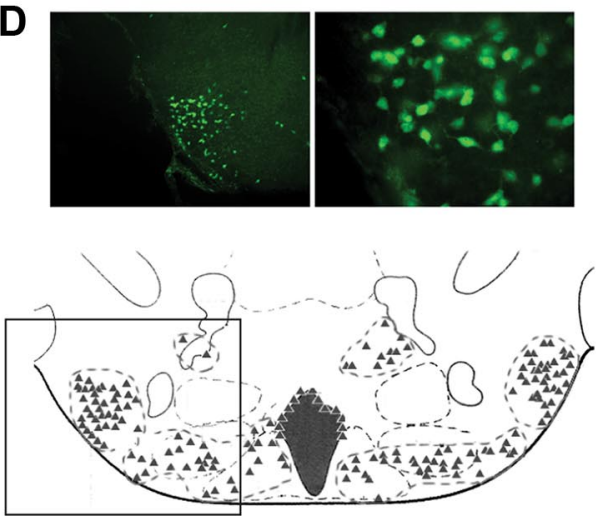

C
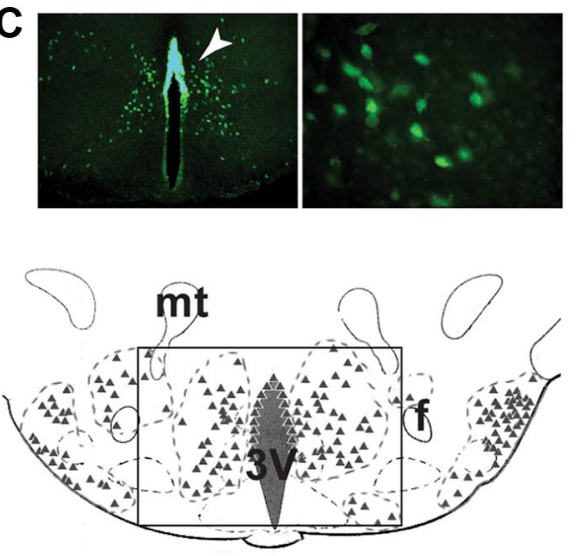

E
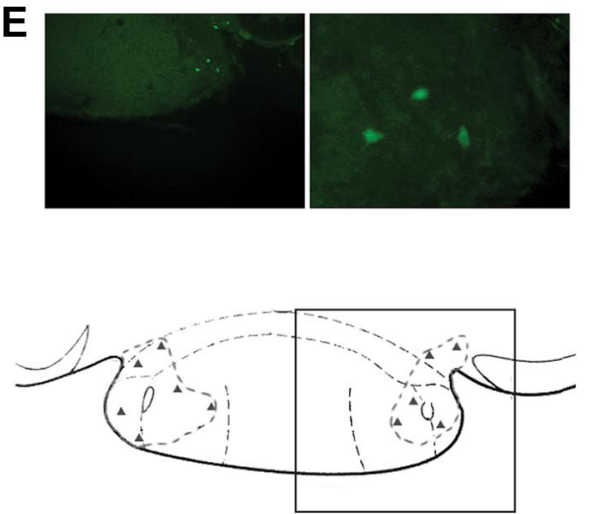

Figure 4. Distribution of EGFP-immunoreactive neurons in the HDC-EGFP mouse. A, Coronal sections through the ventrolateral TMN of an HDC-EGFP mouse brain. Top, A low-magnification image (scale bar, $250 \mu \mathrm{m}$ ). Bottom, High-magnification images (scale bar, $50 \mu \mathrm{m}$ ). Immunostaining against EGFP selectively labeled histaminergic cells in this region, as shown by double labeling with an anti-HDC antibody. EGFP immunoreactivity was also in ependymal cells capping the mammillary recess (arrowhead). $\boldsymbol{B}-\boldsymbol{E}$, We classified histaminergic neurons into three subgroups along the mediolateral axis, beginning with the most rostral and progressing caudally. We mapped the location of each EGFP-positive neuron: their positions are illustrated as triangles. The illustration in $\boldsymbol{B}$ shows these groups as the MTM, DTM, and VTM, respectively. In each panel, a low-magnification image is on the top right (scale bar, $500 \mu \mathrm{m}$ ) alongside a high-magnification image on the top left (scale bar, $50 \mu \mathrm{m}$ ). mt, mammillothalamic tract; f, fornix; $3 \mathrm{~V}$, third ventricle.

\section{HDC neurons lacking synaptic $\mathrm{GABA}_{\mathrm{A}}$ receptors are more excitable}

We performed whole-cell current-clamp recordings in TMN neurons to examine whether the removal of synaptic $\mathrm{GABA}_{\mathrm{A}}$ receptors had affected the excitability of these cells (Fig. 6). TMN neurons from $H D C-\Delta \gamma_{2}$ mice had a resting membrane potential $(\mathrm{RMP})$ of $-45.8 \pm 2.0 \mathrm{mV}(n=9)$ compared with $-49.1 \pm 1.6$ $\mathrm{mV}(n=8)$ in littermates: a small but significant depolarization ${ }^{\star} p<0.05$, Mann-Whitney test). We also observed a significant leftward shift of the action potential frequency-current input
( $f-I$ ) curve in the $\gamma_{2}$ knockout compared with littermate controls (Fig. $6 B$ ). More action potentials were produced for a given amount of current injection, and the current required to reach threshold for action potential generation was significantly $\left({ }^{*} p<0.05\right)$ reduced in the knockout $(5.0 \pm 1.4 \mathrm{pA}, n=9)$ compared with littermate controls $(12.7 \pm 2.3 \mathrm{pA}, n=6$ ) (Fig. 6C). Furthermore, removal of the $\gamma_{2}$ subunit significantly $\left({ }^{* * *} p<0.01\right)$ increased the membrane time constant $\left(\tau_{\mathrm{m}}\right)$ of knock-out neurons $(23.4 \pm 1.7 \mathrm{~ms}, n=9)$ compared with those from littermates $(11.5 \pm 1.7 \mathrm{~ms}, n=8)$, consistent with a loss of channels (Fig. 6D). 
A Littermate
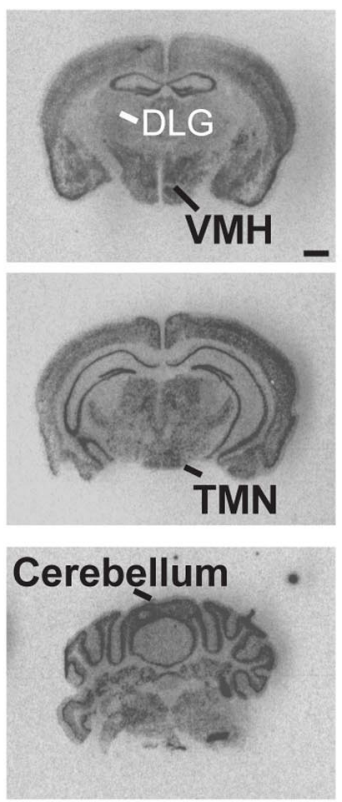

B
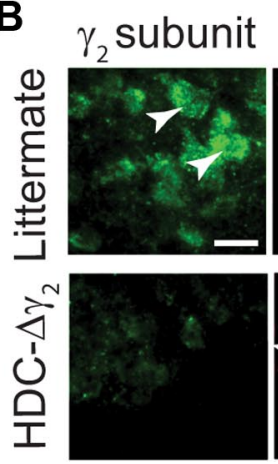
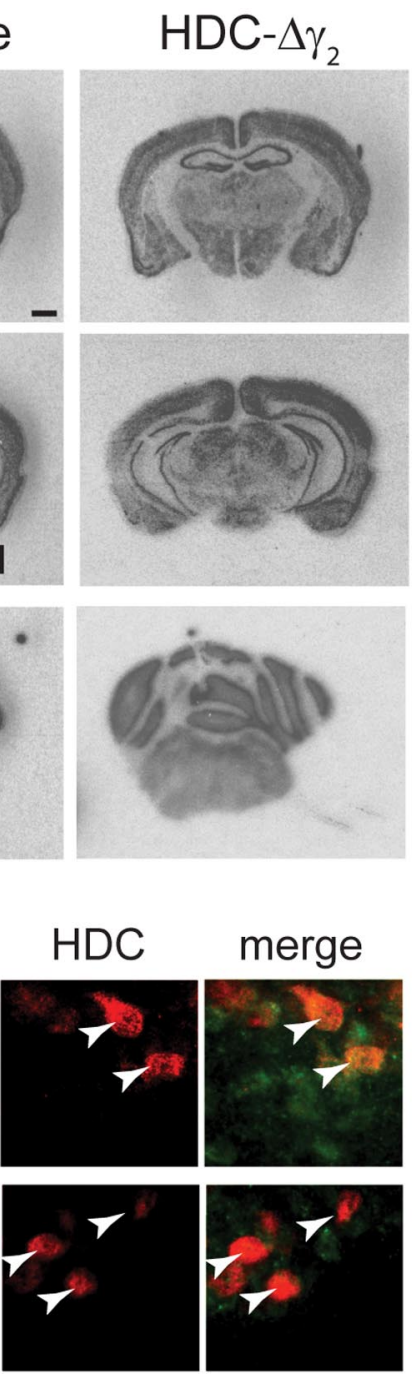

ii)

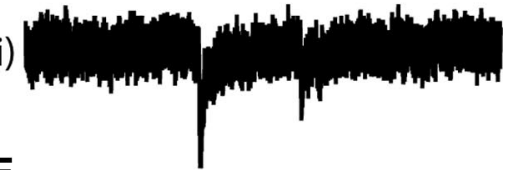

E

C

HDC- $\Delta \gamma_{2}$ TMN

i)

Littermate TMN

ii)

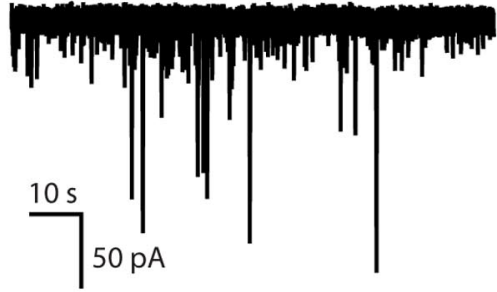

D

\section{Littermate DLG}

i)

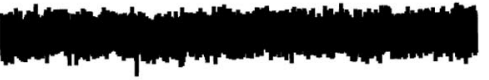

HDC- $\Delta \gamma_{2}$ DLG

i)

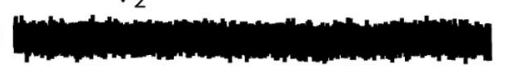

ii)

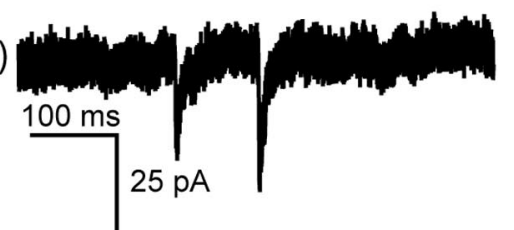

Figure 5. $G_{A B A_{A}}$ receptor $\gamma_{2}$ subunit expression in $H D C-\Delta \gamma_{2}$ mice. $A$, X-ray film autoradiographs showing in situ hybridization of GABA $A_{A}$ receptor $\gamma_{2}$ subunit mRNA in brain sections from littermate control and HDC- $\Delta \gamma_{2}$ adult mice (scale bar, $1 \mathrm{~mm}$ ). B, Brain sections from littermate and HDC- $\Delta \gamma_{2}$ mice were double stained with anti- $\gamma_{2}$ (left) and anti-HDC (middle) antibodies. Merged images of TMN neurons are shown on the right for each genotype (scale bar, $25 \mu \mathrm{m}$ ). $C$, Current traces from whole-cell voltage-clamp recordings from HDC- $\Delta \gamma_{2}$ (top) and littermate (bottom) histaminergic neurons. GABAergic synaptic activity was strongly compromised in knock-out mice compared with littermate controls. $\boldsymbol{D}, \boldsymbol{E}$, Current traces recorded in the DLG from littermate (D) and HDC- $\Delta \gamma_{2}(E)$ adult mice, show this population of neurons comprises cells without (Di, Ei) and with (Dii, Eii) IPSCs in both genotypes.

$\mathrm{GABA}_{\mathrm{A}}$ receptor removal from histaminergic neurons does not affect the sleep-wake cycle

GABAergic inhibition onto histaminergic neurons is hypothesized to produce sleep induction and maintenance (Saper et al., 2010; Haas and Lin, 2012). We therefore examined the sleepwake cycle in HDC- $\Delta \gamma_{2}$ mice (Fig. 7). For this, we used Neurologger 2 devices (Pang et al., 2009; Vyssotski et al., 2009), which allow uninterrupted recordings on untethered mice for $24 \mathrm{~h}$. Recordings were made in the home cage. $H D C-\Delta \gamma_{2}$ and their littermate controls did not differ in any variable examined: EEG power spectrum (Fig. 7B), total sleep-wake time (Fig. 7C), and duration of REM and NREM periods over the $24 \mathrm{~h}$ cycle.

\section{$\mathrm{GABA}_{\mathrm{B}}$ receptor removal from histaminergic neurons does} not affect the sleep-wake cycle

Given the lack of effect of synaptic $\mathrm{GABA}_{\mathrm{A}}$ receptor deletions from histaminergic neurons on the sleep-wake cycle, we next considered whether metabotropic $\mathrm{GABA}_{\mathrm{B}}$ receptors could be playing a role. In $\mathrm{GABA}_{\mathrm{B}}$ receptor total knock-out mice, and those with $\mathrm{GABA}_{\mathrm{B}}$ receptors specifically removed from orexiner- gic neurons, sleep is more fragmented (Matsuki et al., 2009; Vienne et al., 2010). We thus specifically inactivated the $\mathrm{GABA}_{\mathrm{B}}$ receptor $\mathrm{R} 1$ subunit gene in histaminergic cells (see Materials and Methods). The $\mathrm{GABA}_{\mathrm{B}} \mathrm{R} 1$ subunit is essential for the formation of $\mathrm{GABA}_{\mathrm{B}}$ receptors (see Materials and Methods). We crossed the HDC-Cre line with GABAB1-lox mice (Haller et al., 2004) to produce $H D C-\triangle B 1$ mice. By SHIPRA behavioral assessment, mice from these crosses appeared healthy (Table 1). Similar to the results obtained with the $H D C-\Delta \gamma_{2}$ mice, $H D C-\Delta B 1$ mice did not differ in EEG or sleep-wake parameters compared with littermate controls (Fig. 7D-F).

To confirm loss of the $\mathrm{GABA}_{\mathrm{B} 1}$ subunit, we first used in situ hybridization with a $\mathrm{GABA}_{\mathrm{B}} \mathrm{R} 1$-selective oligonucleotide probe. This showed no difference in signal between $H D C-\Delta B 1$ and littermate control coronal sections for any brain region examined (Fig. 8 A). GABA $\mathrm{B}_{\mathrm{B}}$ is found on most, if not all, neuronal cell types (Kulik et al., 2002), and any loss of mRNA hybridization signal from dispersed neurons in the small TMN area would be hard to ascertain (Fig. 5A). However, immunocytochemistry of the ventral TMN area with a $\mathrm{GABA}_{\mathrm{B}} \mathrm{R} 1$-selective antibody revealed se- 
lective loss of $\mathrm{GABA}_{B} \mathrm{R} 1$ subunit in cells that were stained with HDC antibody (Fig. 8B).

\section{$H D C-\Delta \gamma_{2}$ mice have a delayed} habituation to a new environment Activating the histaminergic system produces wakefulness and an enhanced ability to attend to the environment (Parmentier et al., 2002; Haas and Panula, 2003; Passani and Blandina, 2011; Haas and Lin, 2012). We therefore examined $H D C-\Delta \gamma_{2}$ and $H D C-\Delta B 1$ mice and their littermate controls in a "litter change" paradigm, using the Neurologger 2 to assay their behavioral state (Fig. 9). Changing the bedding of the home cage was stimulating for mice: both littermate and $H D C-\Delta \gamma_{2}$ mice were strongly aroused (as shown by the percentage of time spent in the wake phase) on exposure to novelty (i.e., placing them into a new home cage containing clean litter). However, HDC$\Delta \gamma_{2}$ mice took longer to reduce their level of arousal, remaining awake for $254.2 \pm$ $15.6 \min (n=6)$ after the litter change, compared with $184.4 \pm 25.2$ min for littermates $(n=8, p=0.05)$. We calculated the degree of arousal (as measured by time spent in the wake phase; Fig. 9, inset) for each animal for a period of $75 \mathrm{~min}$, starting from when the first sleep episode was observed in the entire cohort. Littermate controls were significantly more variable in this measure $(p<0.0001, F$ test $)$, and were awake on average $83.4 \pm 6.9 \%(n=$ 8) of this 75 min period, compared with $99.8 \pm 0.1 \%$ for $H D C-\Delta \gamma_{2}$ mice $(n=6)$.

The $\mathrm{GABA}_{\mathrm{A}}$ receptor knockouts had a significantly elevated level of arousal $(p<0.05)$. We did the same litter change assay with the $\mathrm{GABA}_{\mathrm{B}}$ receptor-deleted $H D C-\triangle B 1$ mice. Again, mice were highly aroused after exposure to clean bedding, but the arousal level in the 75 min following the first observed sleep period (any animal) was identical $(p>0.5)$ for HDC- $\Delta B 1$ mice (61.2 \pm $11.1 \%, n=8)$ and littermate controls $(60.0 \pm 12.0 \%, n=8)$. So, this effect was selective for fast synaptic inhibition onto histaminergic neurons.

\section{Removal of propofol sensitivity from histaminergic neurons} does not affect propofol-induced loss of righting reflex Histaminergic TMN neurons may be important targets of the general anesthetic propofol (Nelson et al., 2002; Zecharia et al., 2009). This drug enhances the potency of GABA at $\gamma_{2}$ subunit-containing $\mathrm{GABA}_{\mathrm{A}}$ receptors when applied at concentrations that produce LOC in vivo (Franks, 2008). We examined LORR, a correlate of LOC, after intravenous propofol in littermate and HDC- $\Delta \gamma_{2}$ mice (Fig. 10A). Following 10 $\mathrm{mg} / \mathrm{kg}$ propofol (administered into the tail vein), littermates regained their righting reflex after $1.0 \pm 0.3 \min (n=4)$, a similar sleep time to that observed in $H D C-\Delta \gamma_{2}$ mice ( $1.3 \pm$ $0.2 \mathrm{~min}, n=6)$. Duration of LORR was also identical following a higher dose $(30 \mathrm{mg} / \mathrm{kg})$ of propofol: anesthesia time for

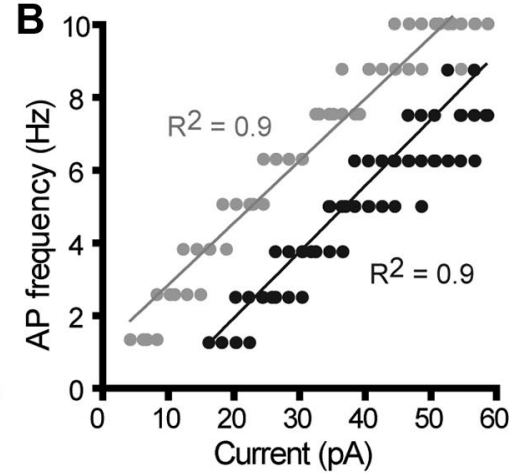

D

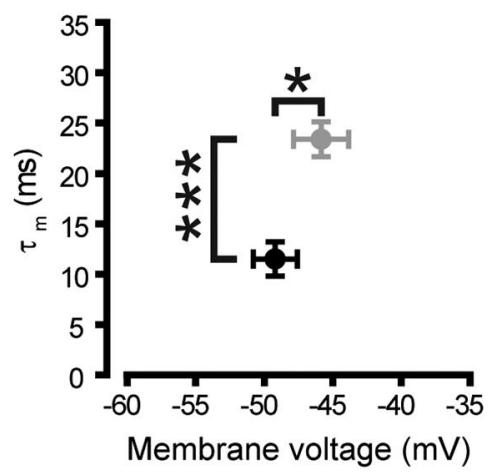

Figure 6. Histaminergic neurons are more excitable in $H D C-\Delta \gamma_{2}$ mice. $A$, Voltage recording from a typical histaminergic neuron with characteristic $I_{\mathrm{h}} \operatorname{sag}\left({ }^{*}\right)$ and transient outward current $\left(^{* *}\right)$. The current injection protocol is shown below (800 ms pulse, -40 to $60 \mathrm{pA}$ in $2 \mathrm{pA}$ increments). $\boldsymbol{B}$, Typical $f-I$ curves for littermate (black) and $H D C-\Delta \gamma_{2}$ (gray) neurons,

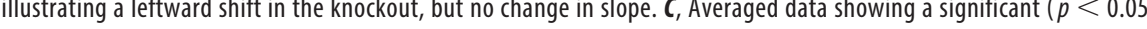
pulse, $100 \mathrm{pA}$ to threshold) and was significantly slower $\left({ }^{* * *} p<0.001\right)$ in knockouts $(23.4 \pm 1.7 \mathrm{~ms})$ compared with littermate controls (11.5 $\pm 1.7 \mathrm{~ms})$.

littermates was $6.3 \pm 0.3 \min (n=4)$ and $5.7 \pm 0.4 \mathrm{~min}$ for $H D C-\Delta \gamma_{2}$ mice $(n=5)$.

We also examined whether the ability of propofol to produce motor sedation was affected by removal of the $\gamma_{2}$ subunit. We administered either $20 \%$ Intralipid vehicle or $50 \mathrm{mg} / \mathrm{kg}$, i.p., propofol to littermates $(n=5)$ and $H D C-\Delta \gamma_{2}$ mice $(n=9)$, and recorded activity levels as a measure of motor sedation. Propofolinduced motor sedation was unaltered: activity was reduced by $51.4 \pm 14.4 \%$ in littermates and by $56.3 \pm 15.1 \%$ in $H D C-\Delta \gamma_{2}$ mice $(p>0.5)$.

However, at the cellular level the ability of propofol to hyperpolarize TMN neurons was abolished by removal of the $\gamma_{2}$ subunit. We performed whole-cell current-clamp recordings in the presence of propofol $(1.5 \mu \mathrm{M})$ and recorded the RMP compared with control ACSF. Propofol significantly hyperpolarized TMN neurons from littermate controls $\left({ }^{* *} p<0.01\right.$, Fig. $10 B$ ) but had no effect on histaminergic neurons recorded in brain slices from the HDC- $\Delta \gamma_{2}$ knock-out mice (Fig. 10C). This indicates that although histaminergic neurons are no longer a cellular target for propofol in the HDC- $\Delta \gamma_{2}$ knock-out mice, these cells are not behaviorally relevant for the actions of the drug.

\section{Discussion}

We studied how fast and slow GABAergic inhibition onto histaminergic neurons regulates behavior. Because the TMN is heterogeneous, and the HDC-positive cells are dispersed (Fig. 4), 


\section{HDC $-\Delta \gamma_{2}$}
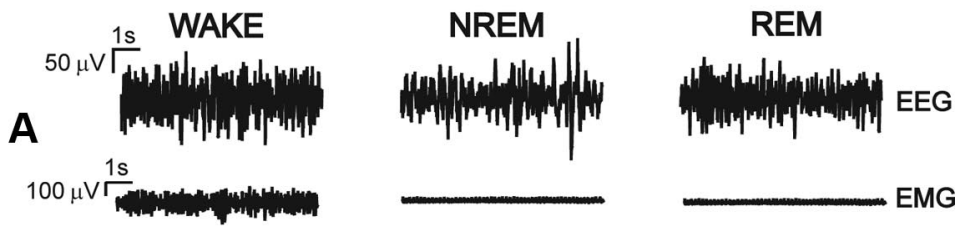

B
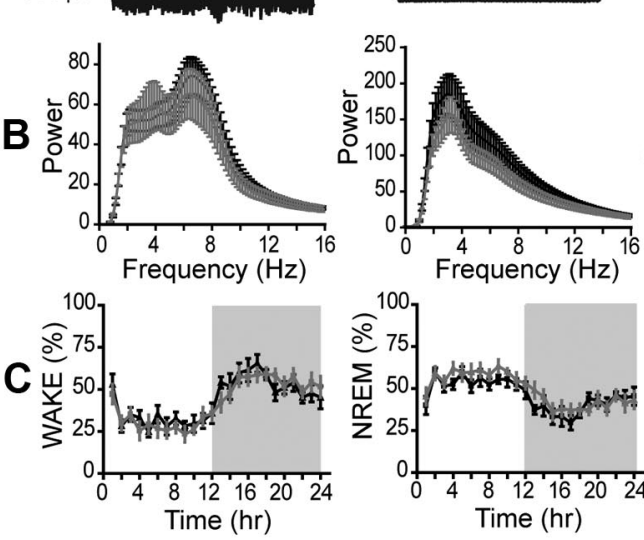

HDC- $\triangle B 1$
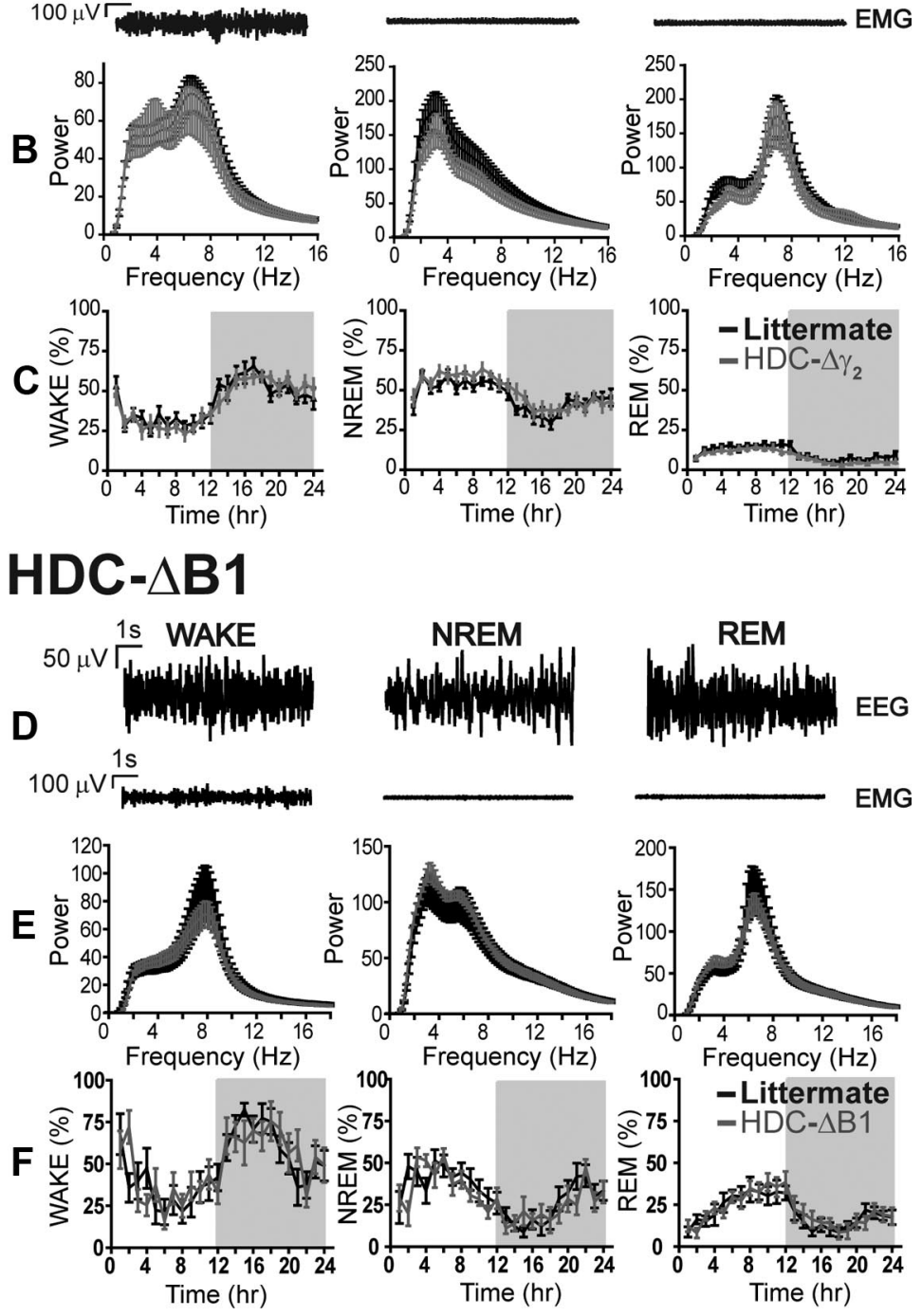

Figure 7. Natural sleep parameters were unchanged in $H D C-\Delta \gamma_{2}$ and $H D C-\triangle B 1$ mice. $A, D$, Representative EEG and EMG traces from littermates during periods of WAKE, NREM sleep, and REM sleep in $H D C-\Delta \gamma_{2}$ and $H D C-\triangle B 1$ mice, respectively. $B$, Power spectral analysis of EEG traces demonstrates that cortical activity in $\operatorname{HDC}-\Delta \gamma_{2}$ mice $(n=9)$ was identical to littermates $(n=9)$ across the three behavioral states. $\boldsymbol{C}$, The time spent in each phase of the sleep-wake cycle was not affected by the $\gamma_{2}$ subunit deletion. $\boldsymbol{E}, \boldsymbol{F}$, Cortical activity $(\boldsymbol{E})$ and time spent in each behavioral state $(\boldsymbol{F})$ were also unchanged in $\operatorname{HDC}-\triangle B 1$ mice $(n=7)$ compared with littermate controls $(n=8)$.

genetic methods have clear advantages. Therefore, we used the Cre/LoxP system to remove ionotropic (fast) and metabotropic (slow) GABAergic signaling from histaminergic neurons and examined the effects on the sleep-wake cycle, how the animals reacted to behavioral stimulation, and propofol-induced motor sedation and loss of righting reflex. Surprisingly, we found that the natural sleep-wake cycle and EEG were unaffected. GABAergic inhibition onto histaminergic cells as a mechanism to induce natural sleep is dispensable. In addition, and contrary to our previous thinking (Nelson et al., 2002; Zecharia et al., 2009), histaminergic neurons also do not seem to be principal cell types for propofol-induced loss of consciousness. However, fast inhi- bition onto histaminergic neurons is needed for an ecologically important behavior, habituation to novelty.

Histamine has an undisputed ability to promote wakefulness: HDC knock-out mice, which cannot synthesize histamine, fall asleep during novel situations and at the start of "lights-off" (Parmentier et al., 2002; Anaclet et al., 2009); and $\mathrm{H}_{1}$ receptor antagonists cause strong sedation (Haas and Panula, 2003; Wafford and Ebert, 2008). Histaminergic neurons have been proposed as the major downstream node through which orexin promotes arousal (Peyron et al., 1998; Eriksson et al., 2001; Huang et al., 2001; Torrealba et al., 2003; John et al., 2004; Mochizuki et al., 2011).

The firing of histaminergic neurons is behaviorally state dependent: they do not fire action potentials during non-REM or REM sleep, start firing action potentials shortly after waking, and fire more during active than quiet waking (Takahashi et al., 2006; Sakai et al., 2010). Much interest centers on what turns histaminergic neurons off at the onset of sleep, keeps them off during sleep, and then turns them on, or allows them to start firing again, shortly after waking. Various transmitters inhibit histaminergic cells (Schönrock et al., 1991; Yang and Hatton, 1997; Oishi et al., 2008), with GABA and galanin being the most prominent (Schönrock et al., 1991; Yang and Hatton, 1997; Sergeeva et al., 2002). The most popular hypothesis is the flip-flop model of sleep-wake switching, whereby GABAergic preoptic hypothalamic nuclei suppress histaminergic firing during sleep (Sherin et al., 1996, 1998; Szymusiak et al., 1998; Saper et al., 2010). The sleep-wake cycle and EEG were unaffected, however, in either $H D C-\Delta \gamma_{2}$ or $H D C-\Delta B 1$ mice. On the other hand, the adaptability and plasticity of the sleep-wake system following chronic tissue or genetic lesions is well known (Blanco-Centurion et al., 2007; Winsky-Sommerer, 2009; Saper et al., 2010). Multiple transmitters and nuclei in the ascending arousal system regulate the sleep-wake cycle. This could indicate that maintaining an unchanged sleep-wake cycle is of such deep importance that many systems can independently preserve it. Yet at a cellular level, $H D C-\Delta \gamma_{2}$ histaminergic neurons have no IPSCs, and are more depolarized and excitable. Other studies have also demonstrated that genetic $\gamma_{2}$ removal ablates synaptic $\mathrm{GABA}_{\mathrm{A}}$ receptors completely, with no "replacement" IPSCs appearing (Schweizer et al., 2003; Wulff et al., 2007, 2009a,b). So, if there has been compensation in $H D C-\Delta \gamma_{2}$ mice, it must be at the systems level. Alternatively, our results may simply mean that inhibition of histaminergic neurons, via GABA at least, plays no role in the regulation of the sleep-wake cycle. 
Alert and attentive waking is associated with elevated histaminergic neuron firing (Takahashi et al., 2006, 2010; Sakai et al., 2010). The HDC- $\Delta \gamma_{2}$ knockouts show that "relaxation," or wind down, of exploratory behavior requires $\mathrm{GABA}_{\mathrm{A}}$, but not $\mathrm{GABA}_{\mathrm{B}}$, receptor-driven inhibition of histaminergic neurons. Eventually, the $H D C-\Delta \gamma_{2}$ knock-out animals do settle, but it takes longer. In other words, habituation to novelty by inhibiting histaminergic neurons is active, not passive, and requires ongoing fast inhibition. This hyperarousal phenotype gives us confidence in concluding that our "negative" results on the sleep-wake cycle reflect the physiological role played by the histaminergic system. During the waking state, inhibitory signals to histaminergic cells could reduce responses to novelty or enable the brain to downplay stimuli. If the environment is nonthreatening and there is little to prompt exploratory behavior, mice show low arousal (i.e., they spend time when not sleeping in a "quiet waking" state). Individuals that waste energy and attract predators by hyperactivity would be at a disadvantage.

Given the potential strategic importance of the inhibitory GABAergic input onto histaminergic neurons in suppressing arousal (see above), we previously suggested that these neurons are key nodes where propofol acts to induce loss of consciousness (Nelson et al., 2002; Zecharia et al., 2009). At the doses used in clinical anesthesia, propofol works as a powerful allosteric modulator of $\mathrm{GABA}_{\mathrm{A}}$ receptors that contain $\beta_{2}$ and/or $\beta_{3}$ subunits (Jurd et al., 2003; Reynolds et al., 2003; Rudolph and Mohler, 2004; Franks, 2008). The drug does not gate the receptors directly, but potently enhances GABA's ability to induce a chloride flux though the receptor; consequently, IPSCs are strongly prolonged. Histaminergic neurons express $\beta_{3}$ subunits (Zecharia et al., 2009), and indeed propofol enhances any active GABA inputs onto histaminergic neurons (Zecharia et al., 2009). At the cellular level, we found that selective deletion of $\alpha \beta \gamma_{2}$-type $\mathrm{GABA}_{\mathrm{A}}$ receptors abolished the inhibitory effects of propofol on histaminergic neurons (Fig. 10). However, at the whole animal level, this had no impact on the ability of this drug to produce motor sedation or loss of consciousness (Fig. 10). Thus, inhibition of histaminergic neurons is probably coincident with, rather than necessary for, the behavioral effects of propofol. This contradicts our previous conclusion based on the effects of local infusion of GABAergic drugs into the TMN region (Nelson et al., 2002): these drugs may have, in fact, reached additional targets.

A

B

\section{Littermate}
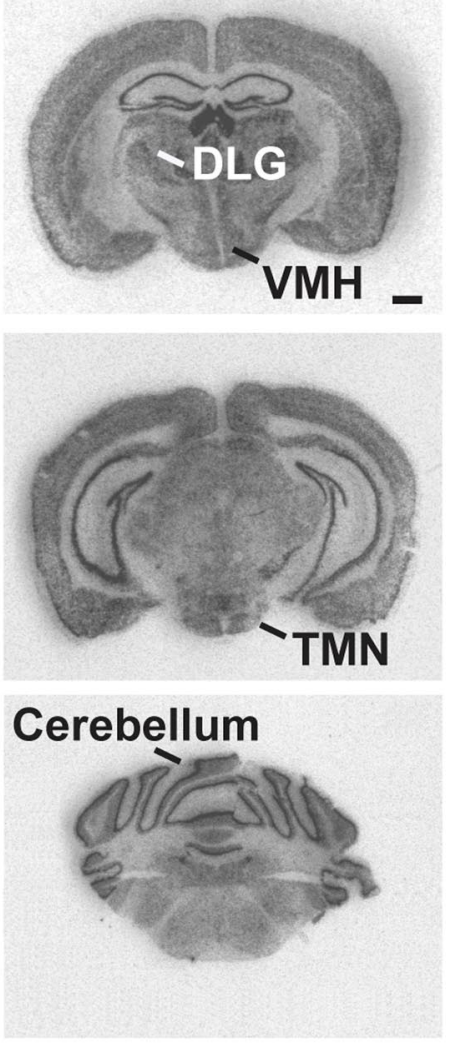

HDC- $\triangle B 1$
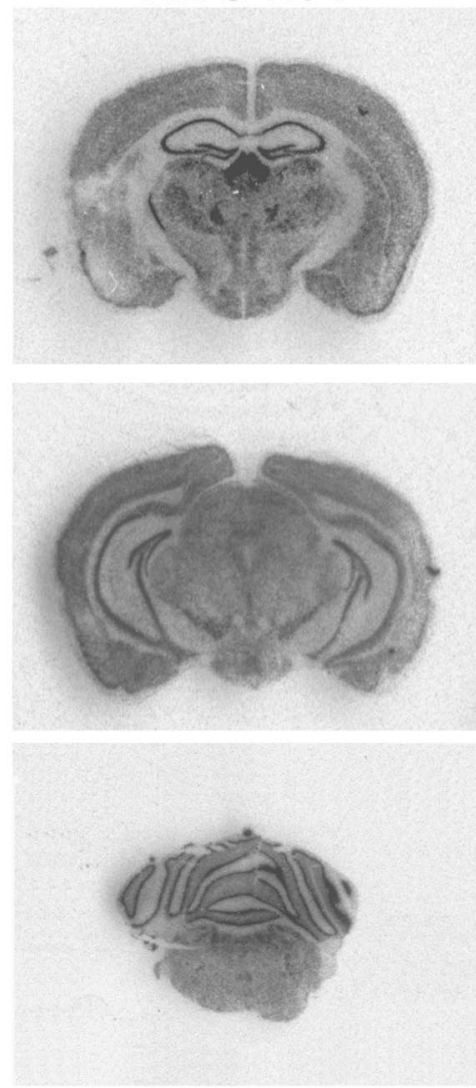
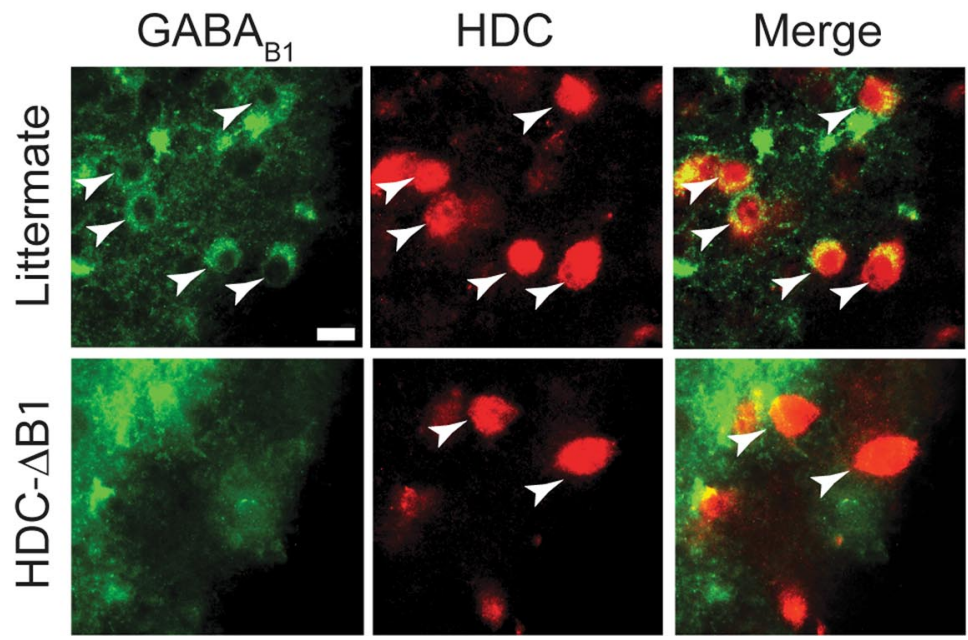

Figure 8. $G A B A_{B 1}$ receptor subunit expression in $H D C-\triangle B 1$ mice. $A, X$-ray film autoradiographs showing in situ hybridization of $G_{A B A_{B 1}}$ receptor mRNA in brain sections from littermate control and $H D C-\triangle B 1$ adult mice (scale bar, $1 \mathrm{~mm}$ ). $\boldsymbol{B}$, Brain sections from littermate and $H D C-\Delta \gamma_{2}$ mice were double stained with anti-B1 (left) and anti-HDC (middle) antibodies. Merged images of TMN neurons (arrowheads) are shown on the right for each genotype (scale bar, $25 \mu \mathrm{m}$ ).

The HDC-Cre mice described here should be useful for studying many aspects of the histaminergic system, but it is necessary to comment on the unexpected Cre expression. For the adult rodent brain, in situ hybridization (Fig. 3A) (Bayliss et al., 1990; Karlstedt et al., 2001) and gene knock-in HDC-EGFP (Fig. 4) mapping all show that HDC gene expression is confined to the TMN and the ependyma. Karlstedt et al. (2001) did not report 

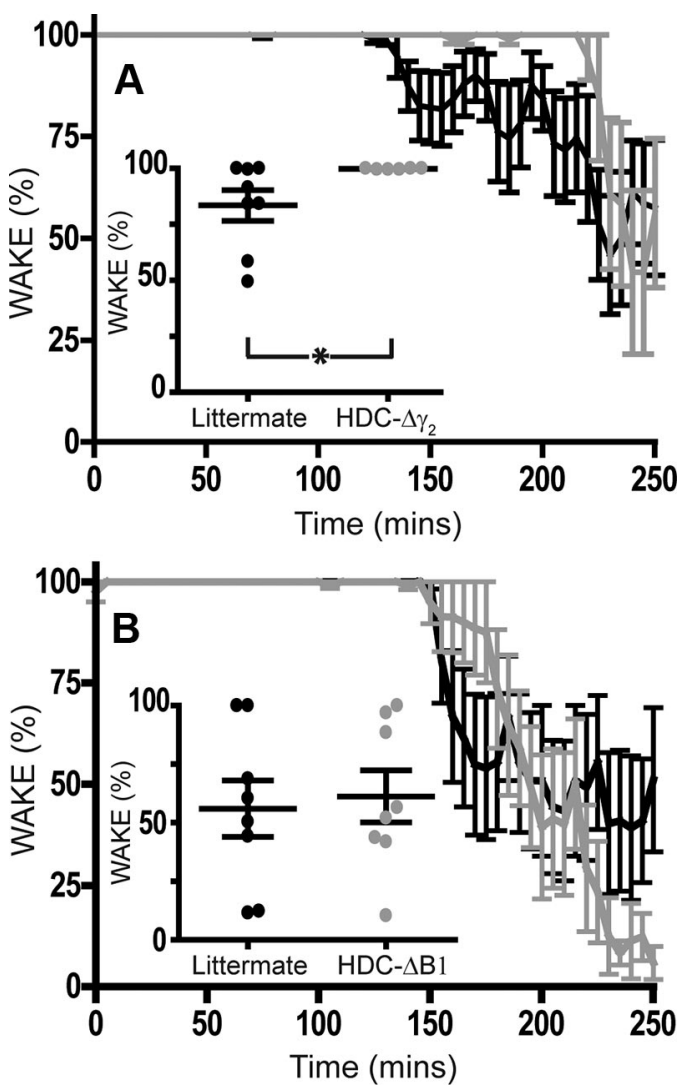

Figure 9. Fast GABAergic synaptic transmission onto histaminergic neurons is essential for habituation to a novel environment. $A$, Both littermate $(n=8)$ and $H D C-\Delta \gamma_{2}(n=$ 6) mice displayed profound arousal on exposure to novelty (i.e., placing them into a new home cage containing clean litter at time 0$)$. However, $\operatorname{HDC}-\Delta \gamma_{2}$ mice took longer to reduce their level of arousal. The main graph shows the percentage of time spent in the wake phase, and the inset shows the percentage of time spent awake for $75 \mathrm{~min}$ following the first observed sleep episode in each cohort $\left.{ }^{*} p<0.05\right)$. B, HDC- $\Delta B 1$ mice $(n=8)$ and littermate controls $(n=8)$ also displayed hyperarousal on being exposed to new litter, but there was no difference between the duration of arousal between genotypes in this case (inset).

developmental expression of the $h d c$ gene in the thalamus during embryonic or postnatal development. The lacZ expression in the $R O S A 26 \times H D C$-Cre crosses was, however, in areas additional to the TMN and ependyma, indicating a probable transient expression of the $h d c$ gene at an earlier time in these circuits. Indeed, when we inspected the on-line, but unannotated, Brain Gene Expression Map (BGEM) in situ hybridization atlas, we found that there was weak expression of the $h d c$ gene in a subset of (undescribed) thalamic nuclei at P7, but not in adults (Magdaleno et al., 2006) (see: http://www.stjudebgem.org/web/ view/probe/viewProbeDetails.php?id = 2069). Therefore, histamine might be synthesized transiently by selected thalamic nuclei during postnatal development. Consistent with the Rosa crosses, approximately two-thirds of the neurons in the DLG thalamic nucleus had disrupted synaptic $\mathrm{GABA}_{\mathrm{A}}$ receptors (Fig. 5Ei). Nevertheless, it is worth emphasizing that a third of the HDC- $\Delta \gamma_{2}$ neurons still had normal IPSCs (Fig. 5 Eii). We think this incomplete penetrance is because floxed gene loci vary in the accessibilities of their loxP sites to Cre recombinase, with some floxed loci requiring strong and sustained Cre expression before recombination occurs (e.g., the floxed Bmal 1 gene) (Husse et al., 2011). It depends on the particular local chromatin structure. The transient develop-
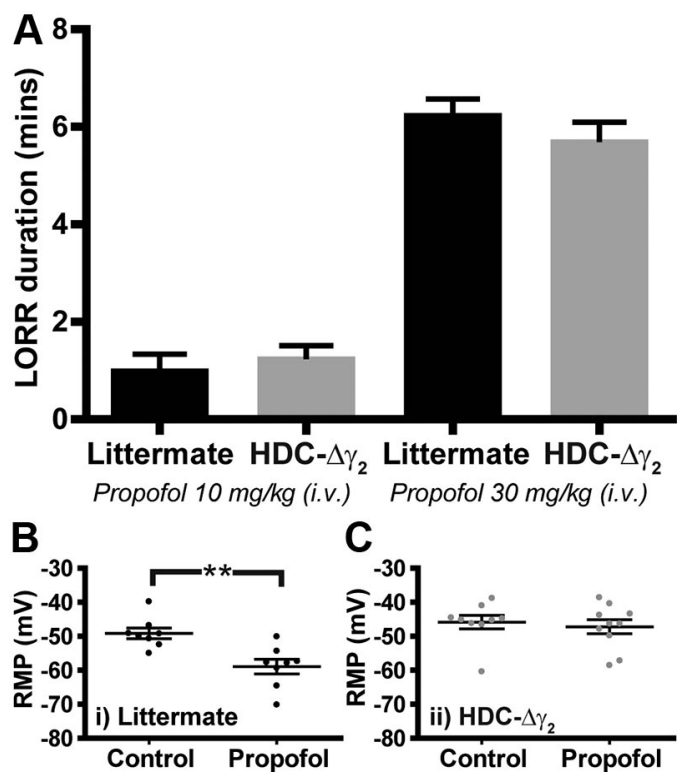

Figure 10. Histaminergic neurons are not a physiological target for propofol anesthesia. $A$, Propofol-induced LORR is identical in HDC $-\Delta \gamma_{2}$ mice compared with littermate controls when administered intravenously at $10 \mathrm{mg} / \mathrm{kg}$ ( $n=6$ and $n=4$, respectively) and $30 \mathrm{mg} / \mathrm{kg}(n=5, n=4$, respectively). $\boldsymbol{B}$, The RMP of TMN neurons was more hyperpolarized in the presence of propofol $(-58.9 \pm 2.2 \mathrm{mV}, n=8)$ compared with control conditions $(-49.1 \pm 1.6 \mathrm{mV}, n=8)$. C, However, in $H D C-\Delta \gamma_{2}$ histaminergic neurons, the control RMP $(-45.8 \pm 2.0 \mathrm{mV}, n=9)$ was unchanged by propofol $(-47.2 \pm 2.1 \mathrm{mV}, n=10)$.

mental IRES-driven expression of Cre in the non-TMN areas might not be sufficient for full recombination at all floxed loci.

Based on the DLG electrophysiology results, a small number of other brain nuclei in the $H D C-\Delta \gamma_{2}$ mice, in addition to the histaminergic neurons, are likely to have some depleted IPSCs. Would these additional deficits contribute to the delayed habituation to novelty of the $H D C-\Delta \gamma_{2}$ mice? Classically, the DLG thalamic nucleus processes visual input; the ventral posterior medial thalamic nucleus handles somatosensory information (Willis, 1997); the VMH nucleus regulates satiety and energy homeostasis (Barsh and Schwartz, 2002). Since the $G_{A B A} R 1$ receptor knockouts generated with the same HDC-Cre line were unchanged on any behavioral parameter, thus serving as further internal controls, we can say that the habituation to novelty deficit is not due to defective GABA inhibition per se.

In summary, the flip-flop model of sleep-wake switching, with its reciprocal inhibitory connections between preoptic hypothalamic nuclei and the TMN, is central to current thinking (Saper et al., 2010). There is certainly a substantial GABAergic innervation of histaminergic neurons (Yang and Hatton, 1997; Sherin et al., 1998; Steininger et al., 2001). However, our data suggest that a primary function of this $\mathrm{GABA}_{\mathrm{A}}$ receptormediated inhibition is to dampen vigilant arousal. It does not appear to influence the loss of consciousness associated with either natural sleep or propofol-induced anesthesia. We believe that other neuronal populations are likely to control this switch, although other factors acting on histaminergic neurons, such as galanin coreleased with GABA from preoptic nuclei (Schönrock et al., 1991), cannot be excluded. Whether propofol targets other circuitry responsible for sleep remains an open question. 


\section{References}

Anaclet C, Parmentier R, Ouk K, Guidon G, Buda C, Sastre JP, Akaoka H, Sergeeva OA, Yanagisawa M, Ohtsu H, Franco P, Haas HL, Lin JS (2009) Orexin/hypocretin and histamine: distinct roles in the control of wakefulness demonstrated using knock-out mouse models. J Neurosci 29: 14423-14438. CrossRef Medline

Bahn S, Jones A, Wisden W (1997) Directing gene expression to cerebellar granule cells using gamma-aminobutyric acid type A receptor alpha6 subunit transgenes. Proc Natl Acad Sci U S A 94:9417-9421. CrossRef Medline

Barsh GS, Schwartz MW (2002) Genetic approaches to studying energy balance: perception and integration. Nat Rev Genet 3:589-600. CrossRef Medline

Bayliss DA, Wang YM, Zahnow CA, Joseph DR, Millhorn DE (1990) Localization of histidine decarboxylase mRNA in rat brain. Mol Cell Neurosci 1:3-9. CrossRef Medline

Belelli D, Peden DR, Rosahl TW, Wafford KA, Lambert JJ (2005) Extrasynaptic $\mathrm{GABA}_{\mathrm{A}}$ receptors of thalamocortical neurons: a molecular target for hypnotics. J Neurosci 25:11513-11520. CrossRef Medline

Belelli D, Harrison NL, Maguire J, Macdonald RL, Walker MC, Cope DW (2009) Extrasynaptic $\mathrm{GABA}_{\mathrm{A}}$ receptors: form, pharmacology, and function. J Neurosci 29:12757-12763. CrossRef Medline

Blanco-Centurion C, Gerashchenko D, Shiromani PJ (2007) Effects of saporin-induced lesions of three arousal populations on daily levels of sleep and wake. J Neurosci 27:14041-14048. CrossRef Medline

Bonin RP, Orser BA (2008) GABA(A) receptor subtypes underlying general anesthesia. Pharmacol Biochem Behav 90:105-112. CrossRef Medline

Bonnerot C, Nicolas JF (1993) Application of LacZ gene fusions to postimplantation development. Methods Enzymol 225:451-469. CrossRef Medline

Brickley SG, Mody I (2012) Extrasynaptic GABA(A) receptors: their function in the CNS and implications for disease. Neuron 73:23-34. CrossRef Medline

Bright DP, Aller MI, Brickley SG (2007) Synaptic release generates a tonic $\mathrm{GABA}_{\mathrm{A}}$ receptor-mediated conductance that modulates burst precision in thalamic relay neurons. J Neurosci 27:2560-2569. CrossRef Medline

Cope DW, Wulff P, Oberto A, Aller MI, Capogna M, Ferraguti F, Halbsguth C, Hoeger H, Jolin HE, Jones A, McKenzie AN, Ogris W, Poeltl A, Sinkkonen ST, Vekovischeva OY, Korpi ER, Sieghart W, Sigel E, Somogyi P, Wisden W (2004) Abolition of zolpidem sensitivity in mice with a point mutation in the $\mathrm{GABA}_{\mathrm{A}}$ receptor gamma2 subunit. Neuropharmacology 47:17-34. CrossRef Medline

Cope DW, Halbsguth C, Karayannis T, Wulff P, Ferraguti F, Hoeger H, Leppä E, Linden AM, Oberto A, Ogris W, Korpi ER, Sieghart W, Somogyi P, Wisden W, Capogna M (2005) Loss of zolpidem efficacy in the hippocampus of mice with the $\mathrm{GABA}_{\mathrm{A}}$ receptor gamma2 F77I point mutation. Eur J Neurosci 21:3002-3016. CrossRef Medline

Costa-Miserachs D, Portell-Cortés I, Torras-Garcia M, Morgado-Bernal I (2003) Automated sleep staging in rat with a standard spreadsheet. J Neurosci Methods 130:93-101. CrossRef Medline

Engle MP, Gassman M, Sykes KT, Bettler B, Hammond DL (2006) Spinal nerve ligation does not alter the expression or function of GABA(B) receptors in spinal cord and dorsal root ganglia of the rat. Neuroscience 138:1277-1287. CrossRef Medline

Eriksson KS, Sergeeva O, Brown RE, Haas HL (2001) Orexin/hypocretin excites the histaminergic neurons of the tuberomammillary nucleus. J Neurosci 21:9273-9279. Medline

Franklin KBJ, Paxinos G (2008) The mouse brain in stereotaxic coordinates. New York: Academic.

Franks NP (2008) General anaesthesia: from molecular targets to neuronal pathways of sleep and arousal. Nat Rev Neurosci 9:370-386. CrossRef Medline

Gassmann M, Bettler B (2012) Regulation of neuronal $\mathrm{GABA}_{\mathrm{B}}$ receptor functions by subunit composition. Nat Rev Neurosci 13:380-394. CrossRef Medline

Günther U, Benson J, Benke D, Fritschy JM, Reyes G, Knoflach F, Crestani F, Aguzzi A, Arigoni M, Lang Y (1995) Benzodiazepine-insensitive mice generated by targeted disruption of the gamma 2 subunit gene of gammaaminobutyric acid type A receptors. Proc Natl Acad Sci U S A 92:77497753. CrossRef Medline

Haas H, Panula P (2003) The role of histamine and the tuberomamillary nucleus in the nervous system. Nat Rev Neurosci 4:121-130. CrossRef Medline

Haas HL, Lin JS (2012) Waking with the hypothalamus. Pflugers Arch 463: 31-42. CrossRef Medline

Haller C, Casanova E, Müller M, Vacher CM, Vigot R, Doll T, Barbieri S, Gassmann M, Bettler B (2004) Floxed allele for conditional inactivation of the GABAB(1) gene. Genesis 40:125-130. CrossRef Medline

Huang ZL, Qu WM, Li WD, Mochizuki T, Eguchi N, Watanabe T, Urade Y, Hayaishi O (2001) Arousal effect of orexin A depends on activation of the histaminergic system. Proc Natl Acad Sci U S A 98:9965-9970. CrossRef Medline

Husse J, Zhou X, Shostak A, Oster H, Eichele G (2011) Synaptotagmin10Cre, a driver to disrupt clock genes in the SCN. J Biol Rhythms 26:379389. CrossRef Medline

Jia F, Pignataro L, Schofield CM, Yue M, Harrison NL, Goldstein PA (2005) An extrasynaptic $\mathrm{GABA}_{\mathrm{A}}$ receptor mediates tonic inhibition in thalamic VB neurons. J Neurophysiol 94:4491-4501. CrossRef Medline

Jia F, Goldstein PA, Harrison NL (2009) The modulation of synaptic $\mathrm{GABA}(\mathrm{A})$ receptors in the thalamus by eszopiclone and zolpidem. J Pharmacol Exp Ther 328:1000-1006. CrossRef Medline

John J, Wu MF, Boehmer LN, Siegel JM (2004) Cataplexy-active neurons in the hypothalamus: implications for the role of histamine in sleep and waking behavior. Neuron 42:619-634. CrossRef Medline

Joseph DR, Sullivan PM, Wang YM, Kozak C, Fenstermacher DA, Behrendsen ME, Zahnow CA (1990) Characterization and expression of the complementary DNA encoding rat histidine decarboxylase. Proc Natl Acad Sci U S A 87:733-737. CrossRef Medline

Jurd R, Arras M, Lambert S, Drexler B, Siegwart R, Crestani F, Zaugg M, Vogt KE, Ledermann B, Antkowiak B, Rudolph U (2003) General anesthetic actions in vivo strongly attenuated by a point mutation in the GABA(A) receptor beta3 subunit. FASEB J 17:250-252. CrossRef Medline

Karlstedt K, Nissinen M, Michelsen KA, Panula P (2001) Multiple sites of L-histidine decarboxylase expression in mouse suggest novel developmental functions for histamine. Dev Dyn 221:81-91. CrossRef Medline

Kulik A, Nakadate K, Nyíri G, Notomi T, Malitschek B, Bettler B, Shigemoto R (2002) Distinct localization of GABA(B) receptors relative to synaptic sites in the rat cerebellum and ventrobasal thalamus. Eur J Neurosci 15: 291-307. CrossRef Medline

Leppä E, Linden AM, Vekovischeva OY, Swinny JD, Rantanen V, Toppila E, Höger H, Sieghart W, Wulff P, Wisden W, Korpi ER (2011) Removal of GABA(A) receptor gamma2 subunits from parvalbumin neurons causes wide-ranging behavioral alterations. PLoS One 6:e24159. CrossRef Medline

Lorez M, Benke D, Luscher B, Mohler H, Benson JA (2000) Single-channel properties of neuronal $\mathrm{GABA}_{\mathrm{A}}$ receptors from mice lacking the gamma 2 subunit. J Physiol 527:11-31. CrossRef Medline

Magdaleno S, Jensen P, Brumwell CL, Seal A, Lehman K, Asbury A, Cheung T, Cornelius T, Batten DM, Eden C, Norland SM, Rice DS, Dosooye N, Shakya S, Mehta P, Curran T (2006) BGEM: an in situ hybridization database of gene expression in the embryonic and adult mouse nervous system. PLoS Biol 4:e86. CrossRef Medline

Matsuki T, Nomiyama M, Takahira H, Hirashima N, Kunita S, Takahashi S, Yagami K, Kilduff TS, Bettler B, Yanagisawa M, Sakurai T (2009) Selective loss of $\mathrm{GABA}(\mathrm{B})$ receptors in orexin-producing neurons results in disrupted sleep/wakefulness architecture. Proc Natl Acad Sci U S A 106: 4459-4464. CrossRef Medline

Mochizuki T, Arrigoni E, Marcus JN, Clark EL, Yamamoto M, Honer M, Borroni E, Lowell BB, Elmquist JK, Scammell TE (2011) Orexin receptor 2 expression in the posterior hypothalamus rescues sleepiness in narcoleptic mice. Proc Natl Acad Sci U S A 108:4471-4476. CrossRef Medline

Nagy A, Rossant J, Nagy R, Abramow-Newerly W, Roder JC (1993) Derivation of completely cell culture-derived mice from early-passage embryonic stem cells. Proc Natl Acad Sci U S A 90:8424-8428. CrossRef Medline

Nelson LE, Guo TZ, Lu J, Saper CB, Franks NP, Maze M (2002) The sedative component of anesthesia is mediated by GABA(A) receptors in an endogenous sleep pathway. Nat Neurosci 5:979-984. CrossRef Medline

Oishi Y, Huang ZL, Fredholm BB, Urade Y, Hayaishi O (2008) Adenosine in the tuberomammillary nucleus inhibits the histaminergic system via Al receptors and promotes non-rapid eye movement sleep. Proc Natl Acad Sci U S A 105:19992-19997. CrossRef Medline 
Olsen RW, Sieghart W (2009) GABA receptors: subtypes provide diversity of function and pharmacology. Neuropharmacology 56:141-148. CrossRef Medline

Pang DS, Robledo CJ, Carr DR, Gent TC, Vyssotski AL, Caley A, Zecharia AY, Wisden W, Brickley SG, Franks NP (2009) An unexpected role for TASK-3 potassium channels in network oscillations with implications for sleep mechanisms and anesthetic action. Proc Natl Acad Sci U S A 106: 17546-17551. CrossRef Medline

Panula P, Yang HY, Costa E (1984) Histamine-containing neurons in the rat hypothalamus. Proc Natl Acad Sci U S A 81:2572-2576. CrossRef Medline

Parmentier R, Ohtsu H, Djebbara-Hannas Z, Valatx JL, Watanabe T, Lin JS (2002) Anatomical, physiological, and pharmacological characteristics of histidine decarboxylase knock-out mice: evidence for the role of brain histamine in behavioral and sleep-wake control. J Neurosci 22:76957711. Medline

Passani MB, Blandina P (2011) Histamine receptors in the CNS as targets for therapeutic intervention. Trends Pharmacol Sci 32:242-249. CrossRef Medline

Peyron C, Tighe DK, van den Pol AN, de Lecea L, Heller HC, Sutcliffe JG, Kilduff TS (1998) Neurons containing hypocretin (orexin) project to multiple neuronal systems. J Neurosci 18:9996-10015. Medline

Pritchett DB, Sontheimer H, Shivers BD, Ymer S, Kettenmann H, Schofield PR, Seeburg PH (1989) Importance of a novel $\mathrm{GABA}_{\mathrm{A}}$ receptor subunit for benzodiazepine pharmacology. Nature 338:582-585. CrossRef Medline

Prosser HM, Gill CH, Hirst WD, Grau E, Robbins M, Calver A, Soffin EM, Farmer CE, Lanneau C, Gray J, Schenck E, Warmerdam BS, Clapham C, Reavill C, Rogers DC, Stean T, Upton N, Humphreys K, Randall A, Geppert M, et al (2001) Epileptogenesis and enhanced prepulse inhibition in GABA(B1)-deficient mice. Mol Cell Neurosci 17:1059-1070. CrossRef Medline

Reynolds DS, Rosahl TW, Cirone J, O’Meara GF, Haythornthwaite A, Newman RJ, Myers J, Sur C, Howell O, Rutter AR, Atack J, Macaulay AJ, Hadingham KL, Hutson PH, Belelli D, Lambert JJ, Dawson GR, McKernan R, Whiting PJ, Wafford KA (2003) Sedation and anesthesia mediated by distinct $\mathrm{GABA}_{\mathrm{A}}$ receptor isoforms. J Neurosci 23:8608-8617. Medline

Rodríguez CI, Buchholz F, Galloway J, Sequerra R, Kasper J, Ayala R, Stewart AF, Dymecki SM (2000) High-efficiency deleter mice show that FLPe is an alternative to Cre-loxP. Nat Genet 25:139-140. CrossRef Medline

Rudolph U, Möhler H (2004) Analysis of GABA ${ }_{\mathrm{A}}$ receptor function and dissection of the pharmacology of benzodiazepines and general anesthetics through mouse genetics. Annu Rev Pharmacol Toxicol 44:475-498. CrossRef Medline

Sakai K, Takahashi K, Anaclet C, Lin JS (2010) Sleep-waking discharge of ventral tuberomammillary neurons in wild-type and histidine decarboxylase knock-out mice. Front Behav Neurosci 4:53. CrossRef Medline

Saper CB, Fuller PM, Pedersen NP, Lu J, Scammell TE (2010) Sleep state switching. Neuron 68:1023-1042. CrossRef Medline

Schönrock B, Büsselberg D, Haas HL (1991) Properties of tuberomammillary histamine neurones and their response to galanin. Agents Actions 33:135-137. CrossRef Medline

Schuler V, Lüscher C, Blanchet C, Klix N, Sansig G, Klebs K, Schmutz M, Heid J, Gentry C, Urban L, Fox A, Spooren W, Jaton AL, Vigouret J, Pozza M, Kelly PH, Mosbacher J, Froestl W, Käslin E, Korn R, et al (2001) Epilepsy, hyperalgesia, impaired memory, and loss of pre- and postsynaptic GABA(B) responses in mice lacking $\operatorname{GABA}(\mathrm{B}(1))$. Neuron 31:47-58. CrossRef Medline

Schweizer C, Balsiger S, Bluethmann H, Mansuy IM, Fritschy JM, Mohler H, Lüscher B (2003) The gamma 2 subunit of GABA(A) receptors is required for maintenance of receptors at mature synapses. Mol Cell Neurosci 24:442-450. CrossRef Medline

Seeburg PH, Wisden W, Verdoorn TA, Pritchett DB, Werner P, Herb A, Lüddens H, Sprengel R, Sakmann B (1990) The GABA receptor family: molecular and functional diversity. Cold Spring Harb Symp Quant Biol 55:29-40. CrossRef Medline

Sergeeva OA, Eriksson KS, Sharonova IN, Vorobjev VS, Haas HL (2002) GABA(A) receptor heterogeneity in histaminergic neurons. Eur J Neurosci 16:1472-1482. CrossRef Medline

Sergeeva OA, Kletke O, Kragler A, Poppek A, Fleischer W, Schubring SR, Görg B, Haas HL, Zhu XR, Lübbert H, Gisselmann G, Hatt H (2010)
Fragrant dioxane derivatives identify beta1-subunit-containing $\mathrm{GABA}_{\mathrm{A}}$ receptors. J Biol Chem 285:23985-23993. CrossRef Medline

Sherin JE, Shiromani PJ, McCarley RW, Saper CB (1996) Activation of ventrolateral preoptic neurons during sleep. Science 271:216-219. CrossRef Medline

Sherin JE, Elmquist JK, Torrealba F, Saper CB (1998) Innervation of histaminergic tuberomammillary neurons by GABAergic and galaninergic neurons in the ventrolateral preoptic nucleus of the rat. J Neurosci 18: 4705-4721. Medline

Shimshek DR, Kim J, Hübner MR, Spergel DJ, Buchholz F, Casanova E, Stewart AF, Seeburg PH, Sprengel R (2002) Codon-improved Cre recombinase (iCre) expression in the mouse. Genesis 32:19-26. CrossRef Medline

Soriano P (1999) Generalized lacZ expression with the ROSA26 Cre reporter strain. Nat Genet 21:70-71. CrossRef Medline

Steininger TL, Gong H, McGinty D, Szymusiak R (2001) Subregional organization of preoptic area/anterior hypothalamic projections to arousalrelated monoaminergic cell groups. J Comp Neurol 429:638-653. 10.1002/1096-9861(20010122)429:4::AID-CNE103.0.CO;2-Y Medline

Stevens DR, Eriksson KS, Brown RE, Haas HL (2001) The mechanism of spontaneous firing in histamine neurons. Behav Brain Res 124:105-112. CrossRef Medline

Suzuki-Ishigaki S, Numayama-Tsuruta K, Kuramasu A, Sakurai E, Makabe Y, Shimura S, Shirato K, Igarashi K, Watanabe T, Ohtsu H (2000) The mouse L-histidine decarboxylase gene: structure and transcriptional regulation by $\mathrm{CpG}$ methylation in the promoter region. Nucleic Acids Res 28:2627-2633. CrossRef Medline

Szymusiak R, Alam N, Steininger TL, McGinty D (1998) Sleep-waking discharge patterns of ventrolateral preoptic/anterior hypothalamic neurons in rats. Brain Res 803:178-188. CrossRef Medline

Takahashi K, Lin JS, Sakai K (2006) Neuronal activity of histaminergic tuberomammillary neurons during wake-sleep states in the mouse. J Neurosci 26:10292-10298. CrossRef Medline

Takahashi K, Kayama Y, Lin JS, Sakai K (2010) Locus coeruleus neuronal activity during the sleep-waking cycle in mice. Neuroscience 169:11151126. CrossRef Medline

Torrealba F, Yanagisawa M, Saper CB (2003) Colocalization of orexin a and glutamate immunoreactivity in axon terminals in the tuberomammillary nucleus in rats. Neuroscience 119:1033-1044. CrossRef Medline

Tretter V, Revilla-Sanchez R, Houston C, Terunuma M, Havekes R, Florian C, Jurd R, Vithlani M, Michels G, Couve A, Sieghart W, Brandon N, Abel T, Smart TG, Moss SJ (2009) Deficits in spatial memory correlate with modified $\gamma$-aminobutyric acid type A receptor tyrosine phosphorylation in the hippocampus. Proc Natl Acad Sci U S A 106:20039-20044. CrossRef Medline

Vienne J, Bettler B, Franken P, Tafti M (2010) Differential effects of GABA receptor subtypes, $\gamma$-hydroxybutyric acid, and baclofen on EEG activity and sleep regulation. J Neurosci 30:14194-14204. CrossRef Medline

Vithlani M, Terunuma M, Moss SJ (2011) The dynamic modulation of $\mathrm{GABA}_{\mathrm{A}}$ receptor trafficking and its role in regulating the plasticity of inhibitory synapses. Physiol Rev 91:1009-1022. CrossRef Medline

Vyssotski AL, Dell'Omo G, Dell'Ariccia G, Abramchuk AN, Serkov AN, Latanov AV, Loizzo A, Wolfer DP, Lipp HP (2009) EEG responses to visual landmarks in flying pigeons. Curr Biol 19:1159-1166. CrossRef Medline

Wafford KA, Ebert B (2008) Emerging anti-insomnia drugs: tackling sleeplessness and the quality of wake time. Nat Rev Drug Discov 7:530-540. CrossRef Medline

Watanabe T, Taguchi Y, Hayashi H, Tanaka J, Shiosaka S, Tohyama M, Kubota H, Terano Y, Wada H (1983) Evidence for the presence of a histaminergic neuron system in the rat brain: an immunohistochemical analysis. Neurosci Lett 39:249-254. CrossRef Medline

Willis WD Jr (1997) Nociceptive functions of thalamic neurons. In: Thalamus: experimental and clinical aspects, vol 2 (Steriade M, Jones EG, McCormick DA, eds). Amsterdam: Elsevier Science.

Winsky-Sommerer R (2009) Role of $\mathrm{GABA}_{\mathrm{A}}$ receptors in the physiology and pharmacology of sleep. Eur J Neurosci 29:1779-1794. CrossRef Medline

Wisden W, Morris BJ, eds (1994) In situ hybridization protocols for the brain. London: Academic.

Wulff P, Goetz T, Leppä E, Linden AM, Renzi M, Swinny JD, Vekovischeva OY, Sieghart W, Somogyi P, Korpi ER, Farrant M, Wisden W (2007) 
From synapse to behavior: rapid modulation of defined neuronal types with engineered $\mathrm{GABA}_{\mathrm{A}}$ receptors. Nat Neurosci 10:923-929. CrossRef Medline

Wulff P, Ponomarenko AA, Bartos M, Korotkova TM, Fuchs EC, Bähner F, Both M, Tort AB, Kopell NJ, Wisden W, Monyer H (2009a) Hippocampal theta rhythm and its coupling with gamma oscillations require fast inhibition onto parvalbumin-positive interneurons. Proc Natl Acad Sci U S A 106:3561-3566. CrossRef Medline

Wulff P, Schonewille M, Renzi M, Viltono L, Sassoè-Pognetto M, Badura A, Gao Z, Hoebeek FE, van Dorp S, Wisden W, Farrant M, De Zeeuw CI (2009b) Synaptic inhibition of Purkinje cells mediates consolidation of vestibulo-cerebellar motor learning. Nat Neurosci 12:1042-1049. CrossRef Medline
Yang QZ, Hatton GI (1997) Electrophysiology of excitatory and inhibitory afferents to rat histaminergic tuberomammillary nucleus neurons from hypothalamic and forebrain sites. Brain Res 773:162-172. CrossRef Medline

Yanovsky Y, Schubring S, Fleischer W, Gisselmann G, Zhu XR, Lübbert H, Hatt H, Rudolph U, Haas HL, Sergeeva OA (2012) GABA receptors involved in sleep and anaesthesia: beta1- versus beta3-containing assemblies. Pflugers Arch 463:187-199. CrossRef Medline

Zecharia AY, Nelson LE, Gent TC, Schumacher M, Jurd R, Rudolph U, Brickley SG, Maze M, Franks NP (2009) The involvement of hypothalamic sleep pathways in general anesthesia: testing the hypothesis using the $\mathrm{GABA}_{\mathrm{A}}$ receptor $\beta 3 \mathrm{~N} 265 \mathrm{M}$ knock-in mouse. J Neurosci 29:2177-2187. CrossRef Medline 